\title{
Ko rāda makrolīmeṇa vērtēšanas darbu analīze eksaktajos mācību priekšmetos trīs gadu periodā
}

\author{
Līga Čakāne, Dace Namsone, Pāvels Pestovs, Dace Bērtule
}

Vērtēšanai makrolīmenī jeb valsts mēroga pārbaudes darbos mērḳis ir zināšanu un prasmju apguves līmeņa konstatēšana noteiktā izglïtîbas posmā. Pašlaik saskaņā ar Ministru kabineta noteikumiem Nr. 1510 "Valsts pārbaudījumu norises kārtība" valsts līmeņa pārbaudījumi (valsts pārbaudes darbi) ir diagnosticējošais darbs un eksāmens. MK noteikumos Nr. 468 "Noteikumi par valsts pamatizglìīibas standartu, pamatizglìīibas mācību priekšmetu standartiem un pamatizglìtîbas programmu paraugiem" nosaukti konkrētie valsts pārbaudījumi, beidzot 3., 6. un 9. klasi. ${ }^{1}$ Valsts izglítības satura centrs (VISC) veido arī citus makrolīmen,a diagnosticējošos darbus, kuriem nav valsts pārbaudỉjuma statuss, piemēram, diagnosticējošais darbs dabaszinātnēs 9. klasei, kura mērkis - "noskaidrot izglītojamo spējas dabaszinātņu mācību priekšmetos iegūtās kompetences izmantot praktisku dabaszinātṇu problēmu risināšanā ar nolūku tās pilnveidot".

Dabaszinātņu apguves mērķis pamatskolā ir dabaszinātniskā izpratība, kas spēkā esošajos šo mācíbu priekšmetu standartos ir strukturēta trīs blokos - izpratne par dabas sistēmām un procesiem; pētnieciskā darbība; vides, sabiedrības

1 Latvijas Republikas Ministru kabineta 2014. gada 12. augusta noteikumi Nr. 468 "Noteikumi par valsts pamatizglìtības standartu, pamatizglìtības mācību priekšmetu standartiem un pamatizglitibas programmu paraugiem".

2 Valsts pārbaudes darbi, beidzot 3., 6. un 9. klasi. Pieejams: http://visc.gov.lv/vispizglitiba/eksameni/dokumenti/programmas/2016_2017/09_dabzin_diagdarbs.pdf

http://visc.gov.lv/vispizglitiba/eksameni/dokumenti/programmas/2016_2017/08_matematika_diagdarbs.pdf (aplūkots 12.02.2018.). 
un tehnologijiju vajadzības, kas veido reālo kontekstu. ${ }^{3}$ Atbilstoši tam skolēna dabaszinātṇu mācišanās rezultāts ir daudzdimensionāls, kas pilnībā var izpausties kompleksā sniegumā. Pretendējot mērīt šo rezultātu, kritiski svarīga kḷūst piemērota vērtēšanas instrumenta izstrāde, sākot ar konstrukta definēšanu, precìzu snieguma indikatoru formulēšanu, snieguma aprakstī̌sanu līmeņos, atbilstošo testelementu atlasi.

\section{Kā tas notiek citur pasaulē}

Vērtēšanas darbi makrolīmenī tiek veidoti ārpus skolas un pārsvarā tiek izmantoti starptautiskajā, nacionālajā vai pašvaldības līmenī. Tradicionāli šāda veida vērtēšana tiek izmantota starptautiskos salīdzinošos pētijumos (Programme for International Student Assessment (PISA), Progress in International Reading Literacy Study (PIRLS) ${ }^{4}$, Trends in International Mathematics and Science Study (TIMSS)), summatīvajai novērtēšanai un mācību programmu novērtēšanai. Līdz ar to vērtēšana makrolīmenī bieži atškiras pēc veida, mērķa un citiem parametriem. Svarīgi ir definēt, kā notiks vērtēšana konkrētajos apstākḷ̣os, lai nebūtu vispārinājuma, kas ir attiecināms uz visiem vērtēšanas darbiem makrolīmenī (Kifer, 2000).

Vairākās valstīs ir mēǵināts apvienot formatīvās un summatīvās vērtēěanas mērķus, kas joprojām ir diskutējams jautājums, lai skolotāja formatīvās vērtēšanas stratēégijas netiktu ierobežotas ar valsts līmeņa summatīviem vērtēšanas darbiem (Black, \& Wiliam, 2007).

Ja vērtēšanas mērḳis ir sertificēšana, t. i., apliecinājuma dokumenta izsniegšana par noteiktu snieguma līmeni, un tā notiek vienā skolā, būtiskais elements darba kvalitātes nodrošināšanai ir visu viena priekšmeta skolotāju iesaiste, vienojoties par pierādījumiem, kuri liecinās par skolēna sasniegumiem atbilstoši sasniedzamajiem rezultātiem mācību priekšmetu standartos. Pašvaldības vai valsts līmenī tas veicams, izmantojot ietvarstruktūru (framework), vērtēšanas darba programmu, kritērijus un kritēriju līmeņu aprakstus par to, ko nozīmē labs sniegums.

3 Latvijas Republikas Ministru kabineta 2014. gada 12. augusta noteikumi Nr. 468. Pieejams: Noteikumi par valsts pamatizglìtības standartu, pamatizglitības mācību priekšmetu standartiem un pamatizglìtības programmu paraugiem. (aplūkots 12.02.2018.).

4 Starptautiskā lasītprasmes novērtēšanas pētījuma IEA PIRLS 2016 pirmie rezultāti par 4. klašu skolēnu lasittprasmi Latvijā un pasaulē. Pieejams: https://www.ipi.lu.lv/fileadmin/user_upload/ lu_portal/projekti/ipi/Publikacijas/elektronisks_PIRLS2016_nacionalais_zinojums.pdf (aplūkots 12.02.2018.). 
Pētījumos (piemēram, Britton, 2007) parādās informācija, ka vērtēšanas darbos ir nepietiekams kompleksu, problēmu risināšanas uzdevumu skaits, bet ir liels zemākam izziņas līmenim atbilstošu uzdevumu īpatsvars.

Pieaug nepieciešamība pēc mērīšanas instrumentu saskaņotības dažādās dimensijās: starp dažādām mācību programmām, mācišanās praksēm un vērtěšanas formām, dažādu klašu grupās un starp dažādām organizācijām (klase, skola, pašvaldība, valsts), saturiski (izziņas, afektīvie u. c.). Jauni mērī̌sanas un datu apstrādes instrumenti l̦auj veikt mērījumus gan starp dažādām populācijām, gan ar vienu un to pašu populāciju dažādos laikposmos, kā arī salīdzināt iegūtos datus (Bond, \& Fox, 2007). Ar mērī̌sanas instrumentu tiek saprasts veids, kas ļauj pēc iespējas precīzāk saistìt skolēna snieguma novērojumus ar to, ko mēs gribam vērtēt, kas ir daḷa no teorētiskā mainīgā (latentais mainīgais, konstrukts) (Wilson, 2005).

Datu analīzei ar nolūku uzlabot vērtēšanas instrumentu un datu interpretāciju izmanto klasiskās testa teorijas - Classic Test Theory (KTT) un testelementaatbildes teorijas - Item Response Theory (TAT) modelus, kuri efektīvi papildina viens otru. KTT izvērtē testelementa grūtības pakāpi, testelementa izškirirtspēju (diskriminācijas indeksu), drošumu. Testelementos ar zemu izšķirtspēju vispirms nepieciešams analizēt formulējumus un testelementa izpildes nosacỉjumus, pēc tam pārliecināties, vai konkrētais testelements mēra definēto konstruktu. L,oti sarežğìti un ḷoti viegli testelementi noved pie zemas izšķirtspējas, bet to ietveršanu vai neietveršanu testā vērtē pret definēto mērḳi. Iekḷaujot testelementus ar zemu izškirtspēju, tiek samazināts testa drošums, palielinās mērījuma kḷūda. Tādējādi samazinās iespēja precīzi interpretēt iegūtos datus. TAT savukārt ḷauj veikt mērīšanas instrumentu pielīdzināšanu, mērot latento mainīgo dažādām grupām, veidot datorizētu adaptīvu testēšanu un interpretēt iegūtos datus. Mērīšanas instrumentam ir jābūt tādam, ka skolēna prasmju līmenis nav atkarīgs no konkrētiem testelementiem, ar kuriem mēra vienu un to pašu prasmi. TAT l̦auj veikt neapstrādāto datu transformāciju, lai iegūtie dati atspoguḷotu arī lineāru sakarību starp skolēnu sasniegumiem. Tas dod papildu iespējas iegūto datu interpretācijai. TAT modelī ir iespēja prognozēt skolēna varbūtību pareizi atrisināt konkrētu testelementu, izmantojot skolēna spēju līmeni un testelementa grūtības pakāpi (Wu, Tam, \& Jen, 2016).

Viens no centrālajiem mērišanas instrumenta komponentiem ir ticamība (validitāte). Ticamības pierādījumi ir nepieciešami vismaz par trim elementiem: mācību saturu, uzdevuma jeb testelementa indikatoru un konstrukta modeli. Lìdztekus ar faktoru analīzi ticamība tiek sasniegta, izmantojot ekspertu diskusijas metodi par satura ticamību un skolēnu intervijas (Liu, 2012). Mērī̌sanas instrumenta veidošanā uzmanība jāvērš uz to, lai atbalstīto iegūtajai datu 
interpretācijai būtu augsta ticamības pakāpe atbilstoši definētajam mērḳim. Mērǐšanas instrumenta veidotājiem izstrādes procesā svarīgi iegūt un dokumentēt pierādījumus drošumam, ticamībai, atbilstîbai plānotajai populācijai un indivīdam. ${ }^{5}$ Kvalitatīva mērī̌sanas instrumenta izveides process ietver:

- izstrādes plānošanu - ticamības izvērtēšanu, datu interpretācijas mērḳi un izmantošanu, mērī̌sanas instrumenta kvalitātes rādītājus;

- ietvara definēšanu - kas tiks mērīts (kādas zināšanas, prasmes, attieksmes), prasības snieguma līmeñiem;

- satura definēšanu - lai efektīvi izstrādātu testelementus;

- uzdevumu testelementu izstrādi un aprobāciju;

- mērīšanas instrumenta izstrādi - formas, satura atbilstību specifikācijai, testelementa formātus, vērtēšanas principus, pielīdzināšanas un izškirtspējas iespējas;

- mērī̌sanas instrumenta publicēšanu;

- mērišanas instrumenta administrēšanu;

- vērtējuma izlikšanu - procedūras testelementa novērtēšanai;

- robežu definēšanu - piemēram, minimāli iespējamo robežu, lai sasniegtu noteiktu lïmeni;

- datu paziņošanu - mērķauditorijai pārskatāmu mērišanas rezultātu apkopojumu;

- mērīšanas instrumenta drošību - procedūras izstrādes un administrēšanas laikā.

Sākot mērīšanas instrumenta veidošanu, būtiski ir izstrādāt mērīšanas instrumenta ietvaru, kurā tiek definēts mērī̌šnas mērḳis, mērḳauditorija, mērīšanas metodologijia, konstrukta modelis, kas būs pārklāts. Mērǐšanas instrumenta sagatavē definē uzdevumu testelementu formu, grūtības pakāpju sadalījumu, testelementu procentuālo sadalijumu katrā no konstrukta dimensijām un apakšdimensijām, kā arī to, kurus lielumus varēs novērot, mērīt tieši, kuri mainīgie būs latenti (Wu, Tam, \& Jen, 2016).

Saistībā ar testelementiem mērišanas instrumentos bieži tiek iekḷauti īso atbilžu uzdevumi, kuru izmantošanas iespējas var paplašināt, mainot formu vai saturu, piemēram, palielinot atbilžu variantu skaitu, prasot izvēlēties vairākas atbildes no piedāvātajām, pievienojot papildu jautājumus - aicinot skolēnu skaidrot, kāpēc tika izvēlēta atbilstošā atbilde u. c. Atbilžu izvēles uzdevumiem piemìt vairākas priekšrocỉbas, piemēram, to formāts l̦auj palielināt satura pārklājumu un iegūt augstu atkārtojamību, bet to izmantošanai ir tendence negatīvi ietekmēt mācỉbu procesu, padarot to virspusēju. Tie nedod iespēju iegūt

5 APA, AERA \& NCME. (2014). Standards for educational and psychological testing. Washington, DC: American Educational Research Association. 
datus par skolēna izvēles pamatojumu un domāšanas gaitu. Viens no virzieniem, kā palielināt šīs formas testelementu efektivitati, ir izmantot atbildes, kas ietver skolēnu nepareizos priekšstatus (Wylie, \& Wiliam, 2006). Otrs trūkums ir saistīts ar šauru un izolētu kontekstu (Black, \& Wiliam, 2007). Strukturētu atbilžu uzdevumi sniedz daudz vairāk informācijas par skolēna domāšanas veidu, bet atbilžu vērtēšanā samazinās drošums, daudz lielāks resurss jāiegulda skolotāju sagatavošanā un vērtētāju vērtēšanas prasmju attīstīšanā. Snieguma vērtēšanai ir izmantojami esejas tipa uzdevumi, bet šai formai piemīt būtiski trūkumi - skolēnam ir nepieciešams liels laika resurss, tādējādi šādu uzdevumu skaits vērtēšanas darbā ir limitēts, nereti darbā tiek iekḷauts tikai viens uzdevums. Šis fakts būtiski ietekmē darba drošumu, jo skolēns spēj uzrādīt augstu sniegumu tāpēc, ka tieši šis jautājums ir derīgs konkrētajam skolēnam. Otrs trūkums ir saistìts ar prasmēm radìt tekstu. Daļa snieguma veidojas no izpratnes konkrētajā nozarē, prasmes argumentēt, bet daļa nepārprotami veidojas no skolēna prasmes radīt tekstu, līdz ar to nevaram būt droši, kas tieši tiek izmērìts.

Saistībā ar makrolīmeṇa mērījumiem tieši dabaszinātṇu jomā skolēnu sasniegumi pārsvarā tiek mērìti multidimensionāli, piemēram, dabaszinātṇu joma sastāv vismaz no četriem saturiskajiem laukiem. Taču pat vienā nozarē skolēnam ir stiprās un vājās puses noteiktos tematos, dabaszinātniskā izpratība var būt atšķirīgos snieguma līmeņos. Metodolog̣ija, kādā veidā informācija tiek apkopota, tiešā veidā ietekmē datu interpretācijas iespējas par individuālo skolēnu vai skolu. Apvienojot individuālā skolēna datus līdz vienam kopìgam snieguma līmenim, netiek iegūti dati par to, ko skolēns patiesībā prot un var izdarìt, jo augsti sasniegumi vienā dạ̦ā var kompensēt zemus sasniegumus citā dạ̦ā. Sasniedzamie rezultāti skolēnam konkrētajā mācišnanās posmā ir ekspertu vienošanās jautājums, līdzīgi ir arī ar robežu starp snieguma līmeņiem. Dabaszinātniskajai izpratîbai ir iespējams definēt dimensijas, vadoties gan no satura, gan pētnieciskajām prasmēm. Definējot pētniecisko prasmju vērtēšanas dimensijas, tiek akcentēts vienojošais dabaszinātṇu jomā (Black, \& Wiliam, 2007).

Kā nozīmīgs pavērsiens atzīmējams tas, ka šobrīd pētnieciskā interese tiek virzìta arī uz mērišanas instrumentu izstrādi metakognitīvo prasmju mērīšanai (Liu, 2012).

Latvijas situācijā būtiski saprast, cik precīzi valsts līmeņa pārbaudes darbi mēra 2006. gada pamatizglìtỉbas mācību satura dokumentos moteiktās prioritātes, vai un kā tie mēra kompleksu sniegumu, kā tie atbilst labam makrolīmeņa mērišana/vērtēšana instrumentam. 


\section{Kā tika analizēti valsts līmeṇa pārbaudes darbi dabaszinātnēs un matemātikā}

Analīzei par trīs gadu periodu (2015-2017) dabaszinātnēs izvēlēti diagnosticējošie darbi 9. klasei. Lai spriestu par tendencēm visā pamatskolas posmā, analizēti arī 6. klases darbi dabaszinībās, un visi valsts līmeṇa darbi matemātikā diagnosticējošie darbi 3., 6. un 8. klasei un eksāmens 9. klasei.

Darbu analīzei izvēlēta trīsdimensionāla ietvarstruktūra (skat. 1. tabulu). Tas atbilst dabaszinātṇu mācību priekšmetu standartu struktūrai - izpratne par procesiem, parādībām dabā; pētnieciskā darbība; kā trešo aspektu izdalot kognitīvo darbību (2006. gadā kā būtisks mācību satura aspekts izcelta problēmrisināšana ar mērḳi veicināt dziḷu domāšanu), lai pārliecinātos, kā skolēni spēj rīkoties situācijās, uzdevumos, kas prasa augsta līmeņa kognitīvu darbību. Tas atbilst arī OECD (the Organisation for Economic Co-operation and Development (OECD)) PISA dabaszinātniskās izpratības mērỉjuma ietvarstruktūrai ${ }^{6}$ (skolēnu prasme zinātniski skaidrot parādības; prasme plānot un vērtēt dabaszinātnisku izpēti; prasme zinātniski interpretēt datus un pierādỉjumus). Skolēns var skaidrot uzdevumu, balstoties gan uz procesu, parādību izpratni, ko ieguvis mācīšanās procesā, gan uz tajā doto informāciju. Arī šādā griezumā svarīgi saprast, vai skolēns spēj darboties tikai atpazī̌anas līmenī vai spēj saskatīt kopsakarības, risināt kompleksu problēmu, cik vienkārši vai kompleksi ir interpretējamie dati, cik skaidrs vai atvērts ir veicamais pētījums; tātad kognitīvais aspekts.

1. tabula. Valsts līmeṇa darbu analīzei izvēlētā ietvarstruktūra

\begin{tabular}{|c|c|}
\hline letvarstruktūras elementi & Izvēlētie kritēriji, mācību satura lauki \\
\hline \multirow{4}{*}{$\begin{array}{l}\text { Izpratne par procesiem, parādībām } \\
\text { dabā, specifiskas prasmes }\end{array}$} & Bioloǵiskās sistēmas un procesi \\
\hline & Fizikālās sistēmas un procesi \\
\hline & Vielas un to pārvērtības \\
\hline & Zemes dabas sistēmas \\
\hline \multirow[b]{2}{*}{ Pētnieciskā darbība } & Ar eksperimenta veidošanu saistītās prasmes \\
\hline & $\begin{array}{l}\text { Prasmes darbā ar informāciju, tostarp grafisku } \\
\text { (tekstpratība) }\end{array}$ \\
\hline Kognitīvais līmenis & Kognitīvais dziḷums \\
\hline
\end{tabular}

6 OECD (2016). PISA 2015 Results (Volume I): Excellence and Equity in Education, PISA, OECD Publishing, Paris. Pieejams: http://dx.doi.org/10.1787/9789264266490-en (aplūkots 12.02.2018.). 
Fiksēts katram kritērijam atbilstošo uzdevumu skaits pārbaudes darbos trīs gadu periodā.

Diagnosticējošā darba analīzē iesaistītie eksperti formulēja katra testelementa indikatoru - zināšanas, prasmes, ko šis uzdevums mēra; noteica katra uzdevuma kognitīvās darbības dziḷumu atbilstoši SOLO (Structure of the Observed Learning Outcome (SOLO)) taksonomijai (Biggs, \& Collis, 1982), prognozējot nepieciešamo kognitīvās darbības līmeni, ko paredz uzdevums. Uzdevumu analīzi veica katrs eksperts individuāli, vērtējumi tika salīdzināti, atšķirību gadījumos diskusiju gaitā vienojoties.

Diagnosticējošā darba analīzē kognitīvās darbības raksturojumam izvēlēta SOLO taksonomija (Biggs, \& Collis, 1982), kur definēti četri snieguma līmeņi, jo šis instruments palīdz detalizētāk ieraudzìt atšķirību starp augstākajiem līmeņiem - ko tieši skolēns demonstrē katrā no tiem, kas ir l̦oti būtiski, ja domājam par nepieciešamību dot skolēniem pieredzi dziḷāk domāt un mērìt sniegumu.

Visiem izvēlētajiem darbiem analizēti gan paši uzdevumi, gan statistiskie dati par skolēnu sniegumu. Diagnosticējošo darbu padziḷinātai analīzei izmantoti arī atlasìti skolēnu darbi. Pieejamie dati (visi skolu iesniegtie skolēnu rezultāti pa uzdevumiem) apstrādāti atbilstoši klasiskajai testa teorijai (Classic Test Theory) un testelementa-atbildes teorijas (Item Response Theory) Raša modelim (Rasch model). Analizējot datus, izmantotas Iteman, Winsteps un $R$ programmas.

Noteikta katra uzdevuma grūtības pakāpe, uzdevuma izškirtspēja, kā uzdevuma izpilde veikusies skolēnu grupai ar augstiem un zemiem sasniegumiem darbā kopumā. Ja uzdevumu veido vairāki apakšuzdevumi (testelementi), grūtības pakāpe noteikta katram no tiem. Ja katrs testelements atbilst citam snieguma indikatoram, tas mēra atšķirīgas zināšanas vai prasmes.

Lai konstatētu pārbaudes darbos iekḷauto uzdevumu piemērotību kompleksa snieguma vērtēšanai, izmantoti kritēriji (skat. 2. tabulu).

2. tabula. Kritēriji uzdevuma piemērotībai kompleksa snieguma vērtēšanai

Izpratne disciplīnā ar fokusu uz būtisko

Starpdisciplinaritāte (pārnesums, integritāte, autentiskums)

Prasmes, tostarp prasmes darbā ar informāciju

Kognitīvās darbības dziḷums

Metakognitīvā darbība

Atbilžu, risināšanas stratēǵiju variativitāte

Vērtēšanas kritēriji 


\section{Kas tiek izmērīts valsts līmeṇa pārbaudes darbos dabaszinātnēs, un kāds ir skolēnu sniegums}

Vispirms atbilstoši izvēlētajam konstruktam noskaidrots, kā tiek mērīta izpratne par procesiem, parādībām dabā.

Satura pārklājums diagnosticējošajos darbos dabaszinātnēs 9. klasei trīs gadu laikposmā redzams 3. tabulā. Šeit aplūkoti tie testelementi, kuri pārbauda skolēnu izpratni par procesiem, parādībām vai nu tiešā veidā, vai kompleksā situācijā.

3. tabula. Testelementu īpatsvars mācību satura laukos (\% no visiem testelementiem) ${ }^{7}$

\begin{tabular}{lccc}
\hline Satura lauks & 2015 & 2016 & 2017 \\
\hline Bioloǵiskās sistēmas un procesi & 20 & 18 & 18 \\
\hline Fizikālās sistēmas un procesi & 18 & 18 & 27 \\
\hline Vielas un to pārvērtī̄bas & 20 & & 27 \\
\hline Zemes dabas sistēmas & 5 & 5 & 6 \\
\hline
\end{tabular}

Tradicionāli vismazāk pārbaudes darbos tiek iekḷauti geogrāfijas satura jautājumi, 2016. gada darbā ķīmijas satura uzdevumu nav vispār. 2017. gadā akcents bijis uz izpratnes mērī̌sanu par procesiem un parādībām dabā, 2016. gadā tam atvēlēts mazāk par pusi testelementu - akcents bijis uz prasmju mērišanu darbā ar informāciju.

Turpmāk analizēts satura lauku atsegums, kā piemērus aplūkojot divus no laukiem, kuri visvairāk pārstāvēti pārbaudes darbos (skat. 4. un 5. tabulu), uzdevuma raksturošanai izmantojot tā grūtỉbas pakāpi (vidējā rezultāta un maksimāli iespējamā punktu skaita attiecỉba) un snieguma indikatoru - ko mēra uzdevums.

Tā kā katrs testelements aplūkots no vairākiem aspektiem, sastopami starpdisciplināri uzdevumi, kompleksi uzdevumi, tad šeit un turpmāk summa var nebūt $100 \%$. 
4. tabula. Indikatori mācību satura laukā "Fizikālās sistēmas un procesi“

\begin{tabular}{|c|c|c|c|c|}
\hline Lauks & Gads & Uzd. & $\begin{array}{l}\text { Grūtības } \\
\text { pakāpe }\end{array}$ & Skolēna snieguma indikators \\
\hline \multirow[t]{4}{*}{ Optika } & 2015 & 6.3 & 0,46 & $\begin{array}{l}\text { Attēlo savācējlēcu, saprotot, ka tā } \\
\text { saistīta ar tālredzību. }\end{array}$ \\
\hline & & 6.4. & 0,43 & $\begin{array}{l}\text { Attēlo, kur fokusējas gaisma normālas } \\
\text { redzes gadījumā. }\end{array}$ \\
\hline & & 6.5. & 0,22 & Aprēkina lēcas fokusa attālumu. \\
\hline & 2017 & 11. & 0,27 & Zina savācējlēcas darbības principu. \\
\hline \multirow[t]{2}{*}{ Elektrība } & 2016 & 7.4 . & 0,64 & $\begin{array}{l}\text { Lieto zināšanas, ka strāva plūst tikai } \\
\text { noslēgtā k̦ēēē, nolasot informāciju no } \\
\text { dotās slēguma shēmas. }\end{array}$ \\
\hline & & 7.5. & 0,53 & $\begin{array}{l}\text { Lieto zināšanas, ka strāva plūst tikai } \\
\text { noslēgtā kēēdē, nolasot informāciju no } \\
\text { dotās slēguma shēmas. }\end{array}$ \\
\hline \multirow[t]{7}{*}{ Siltums } & 2015 & 5.3. & 0,37 & $\begin{array}{l}\text { Saprot, ka sildot pirmā iztvaiko tā } \\
\text { viela, kurai viršanas temperatūra } \\
\text { zemāka. }\end{array}$ \\
\hline & & 8.4. & 0,50 & $\begin{array}{l}\text { Zina, ka gaiss ir labs siltuma izolators, } \\
\text { novēršot siltumvadīšanu. }\end{array}$ \\
\hline & 2016 & 9.3. & 0,29 & $\begin{array}{l}\text { Nolasa informāciju no grafika } \\
\text { un saista ar zināšanām par } \\
\text { siltumizolācijas būtību. }\end{array}$ \\
\hline & & 9.4 & 0,37 & Atpazīst siltuma pārneses virzienu. \\
\hline & 2017 & 3.2. & 0,45 & $\begin{array}{l}\text { Zina, ka, palielinoties temperatūrai, } \\
\text { notiek iztvaikošana, veidojas burbuḷi - } \\
\text { ūdens gāzveida stāvoklī. }\end{array}$ \\
\hline & & 12.1. & 0,36 & $\begin{array}{l}\text { Skaidro konkrēto situāciju } \\
\text { (ledusskapja darbības principu), } \\
\text { izmantojot sakarību enerǵijas apritē. }\end{array}$ \\
\hline & & 12.2. & 0,46 & $\begin{array}{l}\text { Skaidrot konkrēto situāciju, } \\
\text { pamatojoties uz siltumapmainas } \\
\text { principu, ūdens siltumietilpību. }\end{array}$ \\
\hline
\end{tabular}




\begin{tabular}{|c|c|c|c|c|}
\hline Lauks & Gads & Uzd. & $\begin{array}{l}\text { Grūtības } \\
\text { pakāpe }\end{array}$ & Skolēna snieguma indikators \\
\hline \multirow[t]{10}{*}{$\begin{array}{l}\text { Spēki un } \\
\text { mijiedarbība }\end{array}$} & 2015. & 3.3. & 0,27 & $\begin{array}{l}\text { Zina, kas ir potenciālā un kinētiskā } \\
\text { enerǵija. Spriež, kā konkrētajā } \\
\text { situācijā pārvēršas kinētiskā enerǵija. }\end{array}$ \\
\hline & & 6.2 & 0,22 & $\begin{array}{l}\text { Saprot, ka lēcas biezums ir attālums } \\
\text { (celı̌s), ko noiet stars, lieto ātruma } \\
\text { formulu. }\end{array}$ \\
\hline & 2016 & 8.1 & 0,63 & $\begin{array}{l}\text { Lieto zināšanas par blīvumu, } \\
\text { peldēšanas nosacījumiem, analizējot } \\
\text { doto informāciju attēlos un tabulā. }\end{array}$ \\
\hline & & 8.3. & 0,42 & $\begin{array}{l}\text { Lieto zināšanas par peldēšanas } \\
\text { nosacījumiem, lai spriestu jaunā } \\
\text { situācijā, kontekstā. }\end{array}$ \\
\hline & & 8.2. & 0,16 & $\begin{array}{l}\text { Kompleksi lieto zināšanas (Arhimēda } \\
\text { likums, ledus blīvums ir mazāks nekā } \\
\text { izkusušā ledus gabala ūdens blīvums), } \\
\text { lai analizētu jaunu situāciju. }\end{array}$ \\
\hline & 2017 & 9.1 & 0,47 & $\begin{array}{l}\text { Zina, kā darbojas smaguma spēks un } \\
\text { gaisa pretestības spēks. }\end{array}$ \\
\hline & & 9.2 & 0,31 & $\begin{array}{l}\text { Prot aprēkināt smaguma spēku, } \\
\text { zinot brīvās krišanas paātrinājuma } \\
\text { konstanti. }\end{array}$ \\
\hline & & 9.3. & 0,29 & $\begin{array}{l}\text { Analizē kustības ātruma izmainas, } \\
\text { izmantojot tekstā, attēlā un grafikā } \\
\text { doto informāciju. }\end{array}$ \\
\hline & & 9.4 & 0,25 & $\begin{array}{l}\text { Secina par ātrumu, pārvietojumu, } \\
\text { salīdzinot divus atškirīgus viena } \\
\text { procesa grafiskos attēlojumus (no } \\
\text { kuriem viens ir netipisks shematisks } \\
\text { attēls). }\end{array}$ \\
\hline & & 10.1 & 0,14 & $\begin{array}{l}\text { Secina, saistot izpratni par blīvumu } \\
\text { kā materiālu raksturojošu lielumu } \\
\text { ar netipiskā grafiskā formā doto } \\
\text { informāciju. }\end{array}$ \\
\hline
\end{tabular}

Gan apjoma, gan izpratnes mērīšanas nozīmē uzsvars ir bijis uz jautājumiem par spēkiem un mijiedarbību. Šie uzdevumi prasa zināšanu un prasmju lietojumu kompleksās situācijās. Pārējie satura laukiem atbilstošie uzdevumi ir vairāk reproduktīivi. 
5. tabula. Indikatori mācību satura laukā "Bioloǵiskās sistēmas un procesi"

\begin{tabular}{|c|c|c|c|c|}
\hline Lauks & Gads & Uzd. & $\begin{array}{l}\text { Grūtības } \\
\text { pakāpe }\end{array}$ & Skolēna snieguma indikators \\
\hline \multirow{3}{*}{$\begin{array}{l}\text { Organismu } \\
\text { iedalījums }\end{array}$} & 2015 & 12.1 & 0,78 & Tekstā un attēlā atpazīst baktērijas. \\
\hline & & 4.1. & 0,37 & Zina augu/dzīvnieku atškirīgo pazīmi. \\
\hline & 2017 & 15.1 & 0,23 & Attēlā atpazīst sēṇu valsts pārstāvi. \\
\hline \multirow{14}{*}{$\begin{array}{l}\text { Organismu } \\
\text { uzbūve un } \\
\text { funkcijas }\end{array}$} & 2015 & 7.1. & 0,72 & $\begin{array}{l}\text { Starp attēliem atpazīst pareizo attēlu ar } \\
\text { orgānu sistēmu. }\end{array}$ \\
\hline & & 4.4. & 0,48 & $\begin{array}{l}\text { Zina, kura orgānu sistēma veic vielu transportu } \\
\text { organismā. }\end{array}$ \\
\hline & & 10.1 & 0,42 & Skaidro, kādē| izmanto fizioloǵisko šḳīdumu. \\
\hline & & 4.3. & 0,26 & $\begin{array}{l}\text { Zina, kuras vielas pārvietojas no auga lapām } \\
\text { uz saknēm. }\end{array}$ \\
\hline & 2016 & 1.1. & 0,75 & Atpazīst cilvēka orgānu attēlā. \\
\hline & & 1.2. & 0,53 & $\begin{array}{l}\text { Atpazīst cilvēka orgānus dažādi novietotos } \\
\text { attēlos (iepriekš nezināma situācija - } \\
\text { škēersgriezuma spogulattēls). }\end{array}$ \\
\hline & & 1.3. & 0,46 & $\begin{array}{l}\text { Atpazīst cilvēka orgānus dažādi novietotos } \\
\text { attēlos. }\end{array}$ \\
\hline & & 3.4. & 0,44 & $\begin{array}{l}\text { Zina par augu vairošanos, kā gēni var tikt } \\
\text { pārnesti. }\end{array}$ \\
\hline & & 2.3. & 0,18 & $\begin{array}{l}\text { Zina, pēc kuras ārējās pazīmes var spriest, ka } \\
\text { kukainis ir parazīts. }\end{array}$ \\
\hline & 2017 & 13.1 & 0,39 & Zina, ka augi gaismā izdala skābekli. \\
\hline & & 14.2 & 0,65 & $\begin{array}{l}\text { Zina, kāpēc uztura bagātinātāji neaizstāj } \\
\text { pilnvērtīgu uzturu. }\end{array}$ \\
\hline & & 14.3. & 0,54 & $\begin{array}{l}\text { Zina, kad lietot uztura bagātinātājus, izmanto } \\
\text { tekstā doto informāciju. }\end{array}$ \\
\hline & & 15.2 & 0,46 & $\begin{array}{l}\text { Zina, ka vicas un skropstas ir kustību } \\
\text { nodrošinātāji. }\end{array}$ \\
\hline & & 15.3. & 0,42 & $\begin{array}{l}\text { Zina, ka sēnes un monēras noārda organiskās } \\
\text { vielas. }\end{array}$ \\
\hline Šūnas & 2015 & 4.2 . & 0,37 & Zina, kas ir fotosintēze un hloroplasti. \\
\hline
\end{tabular}




\begin{tabular}{lcccc}
\hline \multicolumn{1}{c}{ Lauks } & Gads & Uzd. & $\begin{array}{c}\text { Grūtības } \\
\text { pakāpe }\end{array}$ & Skolēna snieguma indikators \\
\hline $\begin{array}{l}\text { Ekoloǵija, } \\
\text { biotehnolo- } \\
\text { ǵijas }\end{array}$ & 2015 & 9.3. & 0,57 & $\begin{array}{l}\text { Skaidro zooloǵisko dārzu darbinieku rīcību ar } \\
\text { reti sastopamiem abiniekiem. }\end{array}$ \\
\cline { 2 - 5 } & 2016 & 3.2. & 0,46 & Zina, kā var noskaidrot, vai izmantoti G̣MO. \\
\cline { 2 - 5 } & & 3.3. & 0,23 & Spriež, kā var izmantot G̣MO. \\
\hline
\end{tabular}

Analizējot bioloǵijas uzdevumu saturu trīs gadu posmā, redzams, ka no iespējamajiem satura laukiem jautājumi ir par organismu uzbūvi un to funkcijām, bet pārsvarā tiek pārbaudītas atsevišḳu faktu zināšanas, orgānu sistēmu atpazīšana attēlos.

Problēma ir ne tikai satura nevienmērīgs nosegums - katrā no četriem laukiem tiek mērīts kaut kas cits, būtiski atškiras kognitīvais dziļums, kāds tiek sagaidīts - biolog̣ijā specifisku faktu zināšanas (zina, atpazīst), fizikā zināšanu lietošana, tostarp jaunās situācijās; kīmijā dominē uzdevumi, kas pārbauda specifiskas prasmes.

Kādi ir skolēnu rezultāti dabaszinātṇu darbos uzdevumos, kas mēra izpratni par procesiem, parādībām dabā?

Datu analīze rāda, ka mazāk nekā $1 / 3$ skolēnu demonstrē labu sniegumu uzdevumos, kuros nepieciešama konkrēta dabaszinātṇu jomas satura izpratne kompleksā situācijā. Puse (vai nedaudz vairāk) skolēnu atpazīst faktus, lieto zināšanas pazīstamās situācijās.

Nākamais izpētes aspekts atbilstoši izvēlētajai ietvarstruktūrai - skolēnu pètnieciskā darbība kā viena no mācību satura prioritātēm.

Tās apguve nav mazāk būtiska kā izpratnes veidošanās par procesiem un parādībām dabā. Diagnosticējošajos darbos dabaszinātnēs 9. klasei trīs gadu laikā salīdzinoši neliela daḷa uzdevumu dod iespēju parādīt, ko skolēni apguvuši par pētijuma veidošanu vai procedūru (eksperimenta) veikšanu. Ar eksperimenta veidošanu saistīto prasmju mērišana iekḷauta 2015. gadā 10\%, 2016. gadā 13\%, 2017. gadā - 14\% no visiem testelementiem (skat. 6. tabulu).

Analizējot detalizētāk, akcents bijis uz prasmi saskatīt pētāmo problēmu, korekta eksperimenta apstākḷu nodrošināšanu, lielumu izvēli - pētijuma plānošanas prasmēm. Vairumā gadījumu šis prasmes skolēnam jādemonstrē, iegūstot nepieciešamo informāciju no teksta, piemēram, 2016. gada diagnosticējošajā darbā iekḷauti pieci testelementi, kas attiecas uz pētnieciskās darbības prasmēm, no tiem trīs uzdevumos bija jāizmanto dotā (teksts, attēls, grafiks) informācija. 2017. gada diagnosticējošā darba pieci testelementi pārbauda, kā skolēni apguvuši pētijjuma plānošanu, eksperimenta veidošanu, turklāt divos no tiem tekstā dotā informācija palīdz atbildēt uz jautājumu. Piemēram, 8. uzdevumā tekstā teikts: "Jānis pētīja, 
kā svārsta garums ietekmē vienas pilnas svārstības ilgumu. Kuri svārsti vinam jāizvēlas šim pētijumam?" Tālāk dots zīmējums un atbilžu varianti: "jāizvēlas pēc iespējas vairāk svārstu; jāizvēlas visgarākais svārsts; jāsalīdzina dažādu svārstu garums un dažādi atsvari; visam, izņemot svārstu garumu, jābūt vienādam."

6. tabula. Pētnieciskās darbības prasmju mērǐšana diagnosticējošajos darbos dabaszinātnēs 9. klasei

\begin{tabular}{|c|c|c|c|c|}
\hline $\begin{array}{l}\text { Pētnieciskās } \\
\text { prasmes }\end{array}$ & Gads & Uzd. & $\begin{array}{l}\text { Grūtības } \\
\text { pakāpe }\end{array}$ & Skolēna snieguma indikators \\
\hline \multirow{10}{*}{$\begin{array}{l}\text { Pētījuma } \\
\text { plānošana: } \\
\text { pētāmā } \\
\text { problēma, } \\
\text { hipotēze, } \\
\text { lielumi }\end{array}$} & 2015 & 8.2 & 0,42 & $\begin{array}{l}\text { Izvērtēt hipotēzes un rezultātu atbilstību, } \\
\text { izmantojot datus no teksta. }\end{array}$ \\
\hline & \multirow[t]{4}{*}{2016} & 4.1 & 0,76 & $\begin{array}{l}\text { Lieto zināšanas par pētāmo jautājumu, } \\
\text { atrodot informāciju tekstā. }\end{array}$ \\
\hline & & 4.2. & 0,55 & $\begin{array}{l}\text { Izvēlas visbūtiskāko lielumu vienādu } \\
\text { eksperimenta apstākḷ nodrošināšanai. }\end{array}$ \\
\hline & & 9.1 & 0,32 & $\begin{array}{l}\text { Nosaka nemainīgo lielumu, atrodot } \\
\text { informāciju (tekstā, attēlā, grafikā). }\end{array}$ \\
\hline & & 5.2 & 0,31 & $\begin{array}{l}\text { Spriež, analizē, ar kuriem eksperimentiem } \\
\text { varēs iegūt atbildi uz pētāmo jautājumu; } \\
\text { lieto vielu masas nezūdamības likumu jaunāā } \\
\text { situācijā. }\end{array}$ \\
\hline & \multirow[t]{5}{*}{2017} & 2. & 0,35 & $\begin{array}{l}\text { Salīdzina reālas situācijas (naftas noplūde) } \\
\text { un modelētas situācijas apstākḷs. }\end{array}$ \\
\hline & & 4.3. & 0,63 & $\begin{array}{l}\text { Skaidro pētnieciskā eksperimenta } \\
\text { nosacījumus konkrētā piemērā, pamato } \\
\text { kontroleksperimenta nepieciešamību. }\end{array}$ \\
\hline & & 8.1. & 0,37 & $\begin{array}{l}\text { Nosaka izvēlēto neatkarīgo mainīgo, zina, } \\
\text { ka nedrīkst mainīt vienlaikus divus lielumus, } \\
\text { atrod attēlā un atbilžu variantos atbilstošo } \\
\text { situāciju. }\end{array}$ \\
\hline & & 8.2. & 0,31 & $\begin{array}{l}\text { Izvēlas pamatojumu - zina, ka nedrīkst } \\
\text { mainīt vienlaikus divus lielumus, attiecina to } \\
\text { uz konkrēto situāciju. }\end{array}$ \\
\hline & & 13.2. & 0,54 & $\begin{array}{l}\text { Saskata (tekstā, attēlā) iespējamos } \\
\text { eksperimentā maināmos lielumus. }\end{array}$ \\
\hline \multirow{2}{*}{$\begin{array}{l}\text { Eksperimenta } \\
\text { veikšana }\end{array}$} & \multirow[t]{2}{*}{2015} & 5.1. & 0,63 & Atpazīst maisījuma sadalīšanas metodi. \\
\hline & & 10.3. & 0,44 & $\begin{array}{l}\text { Atpazīst, kuri piederumi ir, kuri jāpapildina, } \\
\text { kuru trūkst šk̦īduma pagatavošanai. }\end{array}$ \\
\hline
\end{tabular}




\begin{tabular}{lcccl}
\hline $\begin{array}{l}\text { Pētnieciskās } \\
\text { prasmes }\end{array}$ & Gads & Uzd. & $\begin{array}{c}\text { Grūtības } \\
\text { pakāpe }\end{array}$ & Skolēna snieguma indikators \\
\hline $\begin{array}{l}\text { Datu analīze, } \\
\text { apstrāde, } \\
\text { secināšana }\end{array}$ & 2016 & 4.3. & 0,41 & $\begin{array}{l}\text { Analizē iegūto datu atbilstību eksperimenta } \\
\text { aprakstam, lietojot tekstā (vienlaidus un } \\
\text { vizuālā) iegūto informāciju. }\end{array}$ \\
\cline { 2 - 5 } & 2015 & 8.3. & 0,42 & $\begin{array}{l}\text { Izvēlas pareizo secinājumu, izmantojot datus } \\
\text { no teksta. }\end{array}$ \\
\hline
\end{tabular}

Kādas ir skolēnu pētnieciskās darbības prasmes? Dati rāda, ka 34 skolēnu spēj atrast tekstā pētāmo jautājumu. Tikai nedaudz vairāk par $1 \frac{1}{2}$ spēj izvēlēties visbūtiskāko lielumu vienādu apstākḷu nodrošināšanai eksperimentam. Taču ar uzdevumiem, kas prasa spriešanu, iedziḷināšanos datos vai eksperimenta nosacījumos, tikuši galā tikai aptuveni $40 \%$ un attiecīgi $30 \%$ skolēnu.

Tā kā prasmes darbā ar datiem (informāciju) ir ne tikai pētniekam nepieciešama prasme un diagnosticējošajos darbos liela uzmanība ir pievērsta tekstpratỉbai - prasmēm darbā ar informāciju, tostarp grafisku, šo uzdevumu analīze tiek izdalìta atseviški.

Daudzu valsts līmeņa darbu uzdevumu izpildei izšķirošas ir tieši prasmes darbā ar tekstu. Uzdevumi, kuros nepieciešama prasme darbā ar informāciju, 2015. gadā veido $25 \%$ no visiem testelementiem, 2016. gadā - 38\%, 2017. gadā $42 \%$. Piemēram, 2017. gada diagnosticējošajā darbā 14 no 33 analizētajiem testelementiem skolēniem ir iespēja izmantot prasmi darbā ar informāciju dabaszinātniskā vai reālās dzīves kontekstā. Starp šiem 14 uzdevumiem ir tādi, kuros skolēnam līdztekus prasmei izmantot tekstā doto informāciju nepieciešamas arī priekšmeta specifiskās prasmes (7.1. prasme rakstìt reakcijas vienādojumu) vai atsevišķu jēdzienu izpratne (blīvums uzdevumā 10.1.), izpratne par eksperimenta veidošanu (8.1., 13.2.). Trijos no tiem (1.1., 1.3., 3.1.) mērīta tieši prasme darbā ar tekstu - uzdevums jau satur atbildes veidošanai nepieciešamo informāciju.

Skolēniem salīdzinoši labi veicas uzdevumos, kuru izpildei nepieciešams parādìt vienkāršu atsevišķu prasmi darbā ar informāciju, piemēram, atrast tekstā teikumu, nolasìt skaiț̣us (lielumus) no vienkārša grafika.

Piemēram, ja aplūko prasmi atrast nepieciešamo informāciju tekstā, 9. klašu skolēnu rezultāti ir šādi:

- jādemonstrē atsevišķa vienkārša prasme - atrast (atpazìt) viena veida tekstā (vienlaidus, vizuālā) konkrētu informāciju, piemēram, atrast datus tabulā - veic $60-75 \%$ skolēnu,

- teksts komplicētāks, satur lieku informāciju, jāinterpretē, jāsaista ar pieredzi - veic $20-45 \%$, 
- vienlaikus dažādu veidu informācija - vārdisks teksts, attēls, shēma, grafiks u. c. - veic 35-70\% (rezultātu izkliedi ietekmē katra teksta veida komplicētība un tas, kāda veida informācija jāmeklē).

9. klašu skolēnu sniegums izvēlētajos testelementos, kas pārbauda prasmes darbā ar grafisku informāciju vienā diagnosticējošajā darbā, redzams 7. tabulā. Lìdzīgu sniegumu skolēni uzrāda arī pārējos darbos - 1. attēlā redzams arī skolēnu sniegums dažāda kognitīvā līmeņa uzdevumos par darbu ar grafisku informāciju trīs gadu laikā.

7. tabula. Skolēnu snieguma indikatori testelementos ar grafiski dotu informāciju 2016. gadā

$$
\text { Uzd. }
$$

Skolēna snieguma indikators

Grūtỉbas

pakāpe

\begin{tabular}{llc}
\hline 7.3. & Nolasa vienkāršu informāciju no grafika. & 0,80 \\
\hline 9.2. & $\begin{array}{l}\text { Nolasa vienkāršu informāciju no grafika, lietojot arī tekstā un attēlā } \\
\text { doto informāciju. }\end{array}$ & 0,72 \\
\hline 6.4. & $\begin{array}{l}\text { Nolasa kompleksu informāciju no teksta un grafika, lai spriestu, veidotu } \\
\text { secinājumu, analizējot situāciju (kā dziḷums ietekmē og!̣skābās gāzes } \\
\text { uzglabāšanas iespējas). }\end{array}$ & 0,49 \\
\hline
\end{tabular}

11.2. Analizē tekstā, grafikā un citā vizuālā veidā dotu informāciju par jaunu reālās dzīves situāciju.

11.1. Analizē tekstā un grafikā doto komplekso informāciju par jaunu reālās dzīves situāciju.

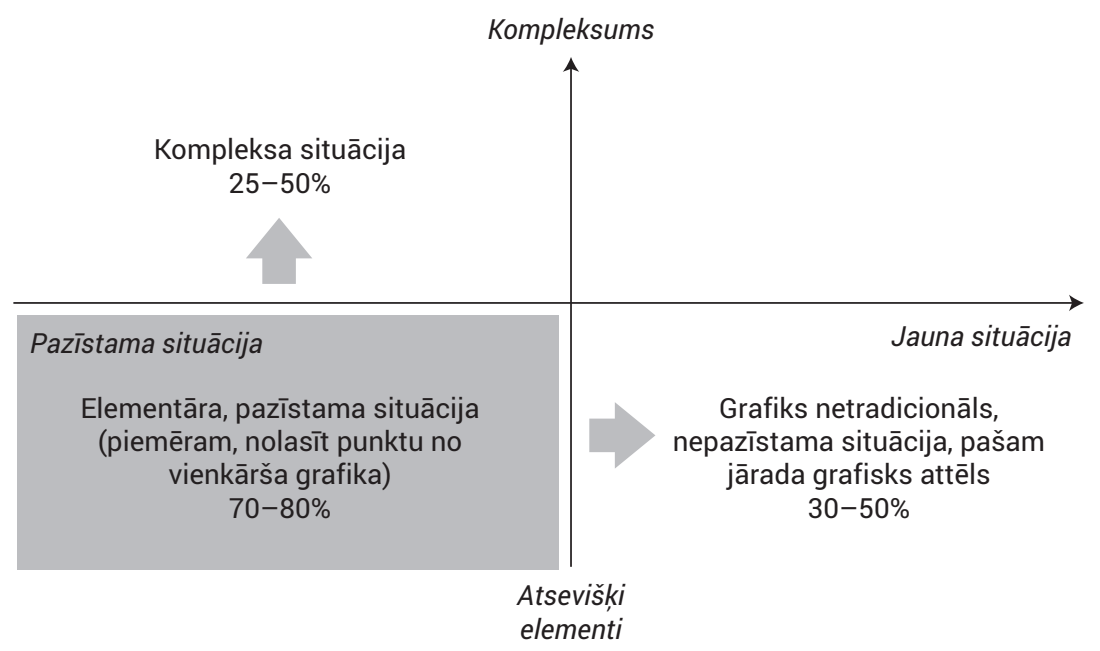

1.attēls. Skolēnu skaits \%, kas spēj veikt darbības ar grafisku informāciju, mainoties uzdevuma kognitīvajam līmenim (LU SIIC arhīvs) 
Turpmāk atbilstoši izvēlētajai ietvarstruktūrai un metodolog̣ijai analizēts valsts līmeņa darbos iekḷauto uzdevumu kognitīvās darbỉbas dziḷms kopumā.

8. tabulā apkopoti dati par valsts līmeṇa darbos iekḷauto uzdevumu kognitīvo līmeni atbilstoši analīzes ekspertu vērtējumam.

8. tabula. Valsts mēroga darbos dabaszinātnēs ieklauto uzdevumu kognitīvais līmenis (testelementu skaits \% katrā līmenī no visiem testelementiem)

\begin{tabular}{cccccc}
\hline \multirow{2}{*}{ 6. klase } & SOLO limenis & I & II & III & IV \\
\cline { 2 - 6 } & 2015 & 33 & 54 & 13 & 0 \\
\cline { 2 - 6 } & 2016 & 52 & 39 & 9 & 0 \\
\hline \multirow{2}{*}{ 9. klase } & 2017 & 41 & 41 & 18 & 0 \\
\cline { 2 - 6 } & 2015 & 20 & 60 & 20 & 0 \\
\cline { 2 - 6 } & 2016 & 32 & 60 & 8 & 0 \\
\hline
\end{tabular}

Konstatēts, ka darbi galvenokārt mēra skolēnu prasmi rīkoties tipveida situācijās. Piemēram, diagnosticējošajos darbos dabaszinātnēs 6. klasei vairāk nekā $80 \%$ no visiem testelementiem prasa zema līmeṇa kognitīvu darbību. Kopumā trīs gadu periodā $64-92 \%$ visu uzdevumu prasa reproduktīvu skolēna darbību faktu un procedūru atcerēšanos, zināšanu un prasmju lietošanu tipveida uzdevumos, vienkāršu datu kopumu interpretēšanu. Šie dati atsedz pretrunu starp 2006. gada satura dokumentos iestrādāto virzỉbu uz produktīvu skolēnu darbību un to, ko mēra valsts līmeña pārbaudes darbi.

N̦emot vērā, ka 2006. gadā kā būtisks mācību satura aspekts izcelta problēmrisināšana ar mērḳi attīstīt dziḷa līmeņa domāšanu, ir nepieciešams pārliecināties, kā skolēni spēj rīkoties situācijās un uzdevumos, kas prasa dažādu līmeṇu kognitīvu darbību.

Darbu statistiska analīze uzrāda, ka arī spējīgāko skolēnu sniegums nereti ir labāks uz reproduktīvu uzdevumu rēķina, piemēram, dabaszinātņu diagnosticējošajā darbā 9. klasei 2017. gadā no testelementiem ar augstu izšķirtspēju (1.1., 1.2., 2., 3.1., 4.2., 8.1., 8.2., 9.2., 13.1., 15.2.) visi, izņemot vienu, ir zema kognitīva lìmeña uzdevumi. Skolēni ar kopumā augstu sniegumu uzrāda lıtoti zemu rezultātu, piemēram, uzdevumā 1.3., kas prasa grafikā dotās informācijas interpretēšanu; 7.2., kur tiek sagaidīta reakcijas vienādojumā redzamās informācijas (koeficienta jēgas) izpratne un pārnešana uz konkrētu situāciju; 9.3. un 9.4. nepieciešama situācijas analīze, demonstrējot tekstā, attēlā, grafikā un netradicionālā shematiskā attēlā dotās daudzveidīgās informācijas interpretāciju, saistī̌sanu. 
Piemēram, 2017. gadā diagnosticējošajā darbā 9. klasei 6. uzdevumu (skat. 2. attēlu) spēja izpildīt tikai $15 \%$ visu skolēnu un tikai $29 \%$ skolēnu, kas darbā kopumā uzrāda samērā augstu rezultātu. Izteikti starpdisciplinārajā šì paša darba 10. uzdevumā rezultāti līdzīgi - to veikuši 14\% visu skolēnu un 30\% no augsta snieguma grupas.

\section{6. uzdevums (1 punkts)}

Anna ir ieplānojusi apstrādāt maurinu ar minerālmēslojumu šḳīdumu. Uz minerālmēslojuma pudeles etiketes ir rakstīts, ka vienu tilpuma dalu minerālmēslojuma nepieciešams sajaukt ar 15 tilpuma dalām ūdens un vienmērīgi izsmidzināt. Cik liels ir nepieciešams minerālmēslojuma tilpums, ja maurina apstrādei vajadzīgi 12 litri škīiduma?
A $750 \mathrm{ml}$
B $800 \mathrm{ml}$
C $1200 \mathrm{ml}$
D $1333 \mathrm{ml}$

2. attēls. Diagnosticējošajā darba uzdevums dabaszinātnēs 9. klasei (VISC, 2017)

Analizējot skolēnu sadalījumu atbilstoši sniegumam, kā piemērs 9. tabulā ir redzama situācija par rezultātiem diagnosticējošajā darbā dabaszinātnēs 9. klasei 2016. gadā.

9. tabula. Skolēnu grupas saskaṇā ar Raša modeli un atbilstošajam SOLO līmenim doto uzdevumu skaits \%

\begin{tabular}{|c|c|c|c|}
\hline $\begin{array}{c}\text { Statistiski } \\
\text { izveidotā } \\
\text { skolēnu grupa }\end{array}$ & Skolēnu snieguma raksturojums & $\begin{array}{c}\text { SOLO } \\
\text { līmenis }\end{array}$ & $\begin{array}{l}\text { Uzdevumu } \\
\text { skaits \% }\end{array}$ \\
\hline $\begin{array}{l}\text { III grupa } \\
\text { (ap } 15 \% \\
\text { no skolēnu } \\
\text { skaita) }\end{array}$ & $\begin{array}{l}\text { Skolēni spēj lietot zināšanas un algoritmus nepazīs- } \\
\text { tamās (jaunās) situācijās, citā kontekstā; analizēt } \\
\text { kompleksu informāciju; radīt risinājumus. }\end{array}$ & III, IV & 8 \\
\hline $\begin{array}{l}\text { Il grupa } \\
\text { (ap } 50 \% \\
\text { no skolēnu } \\
\text { skaita) }\end{array}$ & $\begin{array}{l}\text { Skolēni spēj skaidrot vai lietot zināšanas pazīsta- } \\
\text { mās standartsituācijās, izvēlas atbilstošus pan̄ēmie- } \\
\text { nus vai procedūras (ar diviem vai vairākiem soliem), } \\
\text { strukturē (organizē) un interpretē vienkāršus datus. }\end{array}$ & II & 60 \\
\hline \multirow{2}{*}{$\begin{array}{l}\text { I grupa un } \\
0 \text { grupa } \\
\text { (ap 35\% } \\
\text { no skolēnu } \\
\text { skaita) }\end{array}$} & $\begin{array}{l}\text { Skolēni spēj parādīt elementāras prasmes, atce- } \\
\text { rēties vai atpazīt vienkāršus faktus, jēdzienus vai } \\
\text { procedūras. }\end{array}$ & 1 & 32 \\
\hline & $\begin{array}{l}\text { Skolēni nespēj parādīt elementāras prasmes, atce- } \\
\text { rēties vai atpazīt vienkāršus faktus, jēdzienus vai } \\
\text { procedūras. }\end{array}$ & & \\
\hline
\end{tabular}


Dati rāda, ka skolēni prot veikt uzdevumus, kas prasa reproducēt apgūtās pamatprasmes, lietot tās standartsituācijās (lìdz 85\% skolēnu) un ka skolēnu potenciāls veikt augstāka līmeņa kognitīvas darbības ir lielāks nekā pārbaudes darbā dotās iespējas to demonstrēt.

Gan valsts mēroga pārbaudes darbu satura - uzdevumu kopuma, gan skolēnu snieguma analīze uzrāda problēmas, kam nepieciešams risinājums. Diskutējamie jautājumi ir divi - makrolīmeņa pārbaudes darbu veidošana un mācīšanās process skolā. Vispirms - par nepieciešamajiem risinājumiem pārbaudes darbu veidošanā.

\section{Kāds ir valsts mēroga pārbaudes darbos dabaszinātnēs un matemātikā iekḷauto uzdevumu potenciāls mērīt skolēnu kompleksu sniegumu?}

Saskatāma tendence valsts līmeṇa pārbaudes darbos iekḷaut uzdevumus ar potenciālu mērìt kompleksu sniegumu, bet uzdevumu potenciāls netiek izmantots. Tiek iegūta virspusēja informācija par skolēnu sniegumu.

Augstākā kognitīvā līmeņa uzdevumi prasa no skolēniem prasmi vispārināt, veidot hipotēzes, reflektēt, teoretizēt, radīt; skolēnam nepieciešams paskatīties uz zināmām idejām jaunā, atšksiinīgā veidā. Šie uzdevumi ir kompleksi, un to pamatā ir skolēniem iepriekš nezināma situācija. Kompleksumu veido vairāki nepieciešamo zināšanu un izpratnes elementi un prasmes (gan specifiskas zinātnu jomas, gan vispārējas, starpdisciplināras, piemēram, pan̄ēmieni darbā ar tekstu); konteksts, kas var būt gan konkrētās zinātnes, gan reālās dzìves, gan citu zinātnu konteksts. Parasti šie uzdevumi ir starpdisciplināri, jo tieši tas veido gan kompleksumu, gan situācijas novitāti. Kompleksa uzdevuma piemērs ir 10. uzdevums 2017. gada diagnosticējošajā darbā dabaszinātnēs 9. klasei (skat. 3. attēlu, 10. tabulu). 
10. tabula. Uzdevuma, kas mēra kompleksu sniegumu, padziḷināts raksturojums (VISC, 2017)

\begin{tabular}{|c|c|c|}
\hline Prasmju joma & $\begin{array}{l}\text { Zināšanas un prasmes, kas } \\
\text { nepieciešamas*, lai izpildītu uzdevumu }\end{array}$ & Konteksta radītā jaunā situācija \\
\hline \multirow[t]{2}{*}{$\begin{array}{l}\text { Fizika, kīimija } \\
\text { (jēdzienu izprat- } \\
\text { ne, uzdevuma } \\
\text { jēgas izpratne) }\end{array}$} & $\begin{array}{l}\text { Masa, tilpums, materiāls, blīvums. } \\
\text { Zina, ka dažādiem materiāliem ir da- } \\
\text { žāds blīvums, vienādiem vienāds - b/̄̄- } \\
\text { vums ir materiālu raksturojošs lielums. } \\
\text { Blīvuma jēdzienu var tiešā veidā ne- } \\
\text { lietot - ja materiāli ir vienādi, tad, pa- } \\
\text { lielinoties tilpumam tieši proporcionāli } \\
\text { (tikpat reižu), palielinās masa. }\end{array}$ & $\begin{array}{l}\text { "Kuri akmeṇi veidoti no viena } \\
\text { materiāla" - visticamāk, ka } \\
\text { šāds formulējums mācoties nav } \\
\text { lietots. Varētu būt priekšstats, ka } \\
\text { visi akmeṇi (ieži) ir no vieniem } \\
\text { un tiem pašiem materiāliem. } \\
\text { Uzdevuma tekstā nav norādes } \\
\text { par nepieciešamību izmantot blī- } \\
\text { vuma jēdzienu - to var noprast } \\
\text { no konteksta. }\end{array}$ \\
\hline & $\begin{array}{l}\text { Prasme aprēkināt blīvumu, ja zināma } \\
\text { masa un tilpums. }\end{array}$ & $\begin{array}{l}\text { Nav dotas/nav zināmas mērvie- } \\
\text { nības, kas nav raksturīgi mācību } \\
\text { uzdevumiem fizikā. }\end{array}$ \\
\hline \multirow[t]{3}{*}{$\begin{array}{l}\text { Matemātika } \\
\text { (sakarību un } \\
\text { tam atbilstošā } \\
\text { grafika izpratne } \\
\text { un izmantoša- } \\
\text { na, aprēḳinu } \\
\text { veikšana; } \\
\text { spriešana) }\end{array}$} & $\begin{array}{l}\text { Kā koordinātu plaknē novietoti pun- } \\
\text { kti, kuru koordinātas saista tiešās } \\
\text { proporcionalitātes sakarība - grafiks } \\
\text { ir taisne, kas iet caur (0; 0) un abi } \\
\text { punkti atradīsies uz šīs taisnes. Tiešāā } \\
\text { proporcionalitāte kā lineāras funkcijas } \\
\text { speciālgadījums. } \\
\text { Var nelietot minētos jēdzienus, bet } \\
\text { spriest, piemēram, - ja izvēlas vienu } \\
\text { punktu (akmeni), kur var atrasties tāda } \\
\text { paša materiāla akmeṇi (ja tilpumu } \\
\text { palielina ... reižu, arī masa palielinās } \\
\text { tikpat reižu). }\end{array}$ & $\begin{array}{l}\text { Uzdevuma formulējums nesatur } \\
\text { nekādas norādes par iespējām } \\
\text { izmantot konkrētas matemātikas } \\
\text { zināšanas un prasmes - mate- } \\
\text { mātiskās prasmes citas zināt- } \\
\text { nes/reālās dzīves kontekstā. }\end{array}$ \\
\hline & Prasme spriest induktīvi/deduktīvi. & \\
\hline & $\begin{array}{l}\text { Prasme izpildīt darbības ar skaitliem } \\
\text { (dalīt veselus skaițus un daḷskaițus), } \\
\text { salīdzināt daḷskaițus (ja izvēlas no- } \\
\text { teikt katra akmens blīvumu). }\end{array}$ & \\
\hline $\begin{array}{l}\text { Informācijas } \\
\text { iegūšana } \\
\text { (grafiskas } \\
\text { informācijas } \\
\text { lasīšana un } \\
\text { interpretēšana) }\end{array}$ & $\begin{array}{l}\text { Prasme nolasīt no grafika datus par } \\
\text { doto punktu, ja informācija nav pie- } \\
\text { tiekama/pilnīga - dotā informācija } \\
\text { nolasot jāinterpretē. }\end{array}$ & $\begin{array}{l}\text { Nav dotas mērvienības - jāiz- } \\
\text { manto nenosauktas (izmanto } \\
\text { tikai skaitlisko vērtī̄bu) vai jāde- } \\
\text { finē/jāpieṇem kāda vienība pat- } \\
\text { valīgi un jāizmanto kā piemērs. } \\
\text { Absolūti netipiska situācija, jo } \\
\text { mācoties tiek uzsvērta nepiecie- } \\
\text { šamība pie asīm norādīt mērvie- } \\
\text { nības un, grafikus lasot, primāri } \\
\text { pievērst uzmanību tam, kādas ir } \\
\text { dotās mērvienības. }\end{array}$ \\
\hline
\end{tabular}




\begin{tabular}{lll}
\hline \multirow{2}{*}{ Prasmju joma } & \multicolumn{1}{c}{$\begin{array}{c}\text { Zināšanas un prasmes, kas } \\
\text { nepieciešamas*, lai izpildītu uzdevumu }\end{array}$} & Konteksta radītā jaunā situācija \\
\hline Risināšanas & Izvēle sākt ar grafiski dotās infor- & Vai skolēnam ir pieredze, kā \\
stratēǵijas & mācijas vispusīgu apjēgšanu (ko & rīkoties, ja nav gatavs skaidrs \\
izvēle & te vispār var ieraudzīt); jautājumā & algoritms? Ko dara skolēns, ja \\
(iespējamo & minēto punktu pāru izpēte; doto un ar & nav metakognitīvo prasmju/ \\
stratēǵiju & tiem saistīto jēdzienu apzināšana un & stratēġiju? \\
apzināšana) & izmantošana. & \\
\hline
\end{tabular}

* Konkrētā nepieciešamība atkarīga no risinājuma stratēǵijas izvēles.

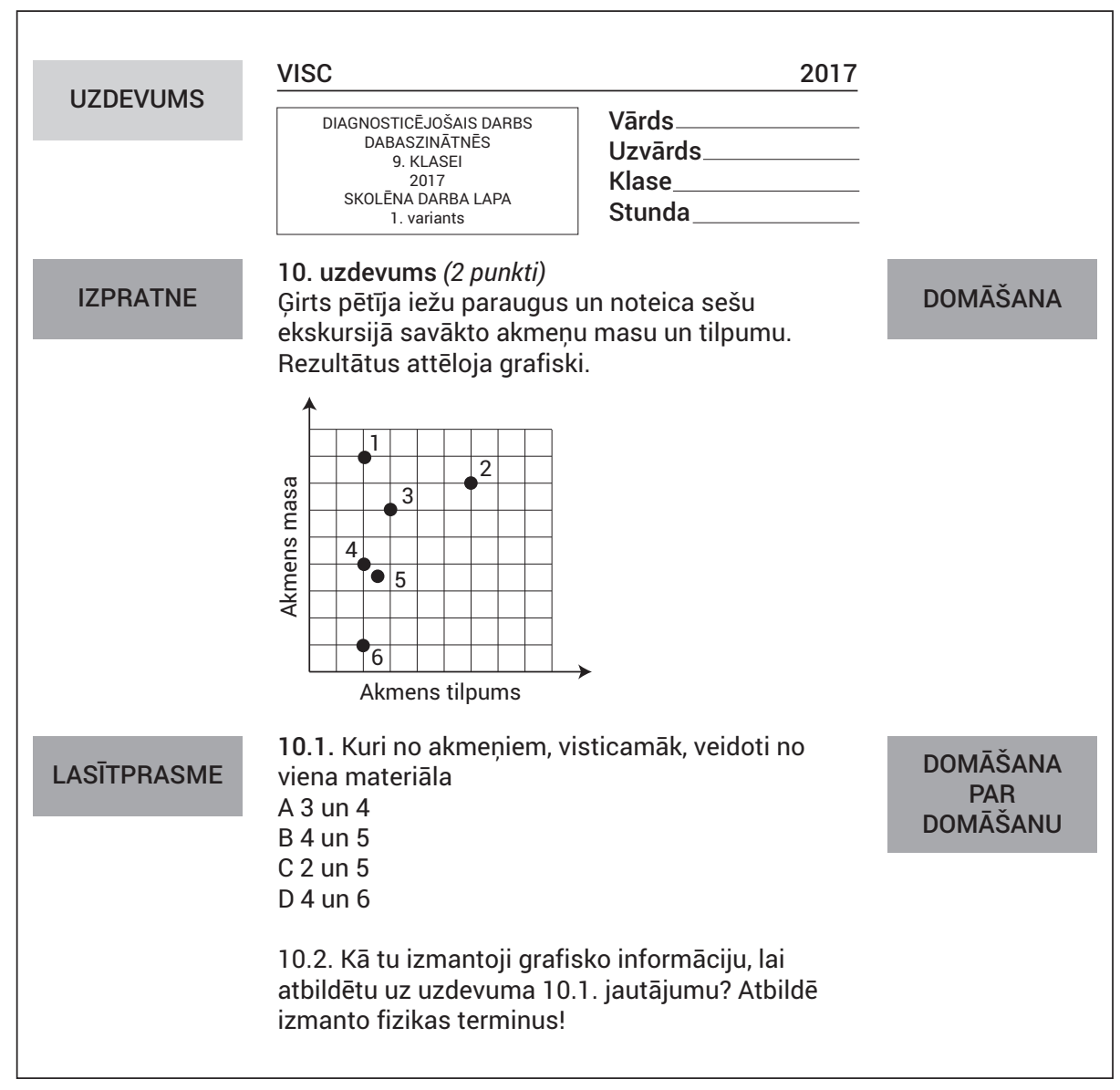

3. attēls. Diagnosticējošā darba uzdevums dabaszinātnēs 9. klasei (VISC, 2017) 
Analizējot katra atsevišḳa uzdevuma kvalitāti, mērḳis bija konstatēt uzdevumu atbilstỉbu, izmantojamību kompleksa snieguma vērtěšanai. Kāpēc tas ir būtiski? Kā norāda citi zinātnieki - mainoties prasmēm, kas skolēniem jāapgūst 21. gadsimtā, ir jāmainās arī pieejai vērtěšanai, jo svarīgas ir ne tikai zināšanas, bet arī tas, ko skolēns spēj ar tām paveikt (Darling-Hammond, \& Adamson, 2010).

Valsts līmeṇa darbos dabaszinātnēs un matemātikā trīs gadu periodā vērojama tendence, ka tiek iekḷauti uzdevumi ar potenciālu mērīt kompleksu sniegu$\mathrm{mu}$, bet šis uzdevuma potenciāls netiek izmantots, dodot iespēju iegūt salīdzinoši virspusēju informāciju par skolēna sniegumu. Darbos sastopami uzdevumi, kuru konteksts ir veiksmīgs un kuri, tos nedaudz pārveidojot - pārformulējot pašu uzdevumu, no kognitīi virspusējiem iegūtu iespēju mērìt daudz augstāka līmeņa kognitiviu skolēna darbību.

Konstatēts, ka ne tikai neprecīzi definēti snieguma indikatori uzdevumiem, bet arī vērtēšanas kritēriji ne vienmēr ir korekti. Tas ne tikai nesniedz iespēju precīzi konstatēt skolēnu prasmes - nekorekti formulēti snieguma indikatori un vērtēšanas kritēriji dot aplamu ziņu skolotājam un skolēniem par mācišanās mērḳiem un veidu. Ja tie precīzi aprakstītu sagaidāmo sniegumu, varētu palīdzēt veidot atbilstošu mācīšanos.

Precīzu vērtēšanas kritēriju formulēšana, aprakstǐšana, kā arī vērtējuma izlikšana ir viens no būtiskākajiem aspektiem kvalitatīvu vērtēěanas instrumentu izstrādē. Valsts pārbaudes darbos dabaszinātnēs un matemātikā joprojām pamatā tiek izmantota pieeja - pareiza/nepareiza atbilde, kas tiek fiksēta punktos 0/1. Šāda pieeja izmantojama, ja nepieciešams konstatēt faktu zināšanas, bet neḷauj spriest par prasmēm, domāšanas dziḷumu, ko darbi pretendē mērìt. Vērtējot vajadzētu skaidri zināt, ko vērtē - zināšanas vai prasmi. Prasmi var novērtēt kā sniegumu, bet ne kā formālu rezultātu (pareizi/nepareizi). Ja gribam ieviest dziḷu mācīšanu, tad vajadzētu mērīt arī prasmi, ko var izdarìt, veidojot snieguma līmeņu aprakstus.

Uzdevumu padzilināta analīze izvēlētajā ietvarā (skat. 11. tabulu) palīdz ne tikai konstatēt faktu, spriest par uzdevuma kvalitāti (kā to dara?), bet arī ieraudzīt, kā šo uzdevumu iespējams pilnveidot (kā darìt labāk?). Kā piemēru aplūkosim divu uzdevumu analīzi. 11. tabulā parādīta 3. klases uzdevuma (skat. 4. attēlu) salīdzinošã analīze. 


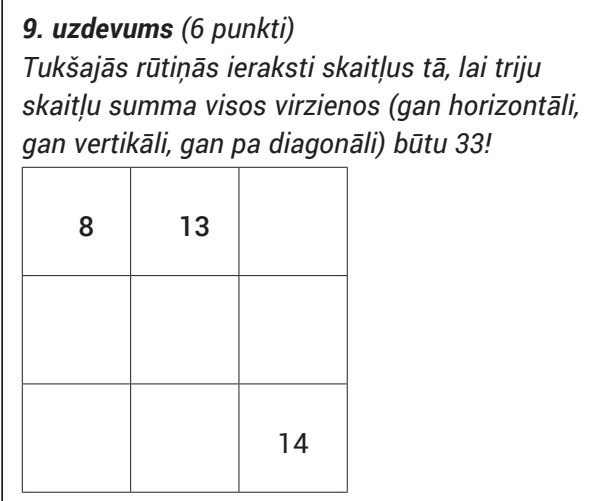

4. attēls. Diagnosticējošā darba uzdevums matemātikā 3. klasei (VISC, 2016)

Šì uzdevuma problēma ir vērtēšanas kritēriji. Dotajos vērtēšanas kritērijos paredzēts punkts par katru pareizi aprēḳinātu trūkstošo skaitli - par katru aizpildītu rūtiņu (turklāt tādā secībā, kādā tās ir izvietotas kvadrātā, nevis secībā, kā tās pakāpeniski iespējams aizpildīt). Tātad skolēnam iespējams iegūt 6 punktus par pilnīgi pareizu formālu atbildi, bet tā nesniedz nekādu informāciju par skolēna domāšanu, šajā uzdevumā nepieciešamo prasmju līmeni. Tā kā šis ir diagnosticējošais darbs, tad vērtēšanas procesā būtu jāsaṇem precīzas atbildes uz jautājumiem, ko tieši skolēns prot labi un kādas prasmes vēl nav pietiekamā līmen̄ī, jo uzdevums pārbauda skolēnu prasmi veikt saskaitīšanas darbības, atrast nezināmo saskaitāmo, ja summa dota (turklāt ne tiešā veidā - šo informāciju jāspēj nolasīt no teksta), un to visu lietot jaunā situācijā, izdomājot stratēgiju, kā rīkoties - kādā secība iespējams rūtiņas aizpildìt.

11. tabula. Uzdevuma matemātikā 3. klasei analīze

\begin{tabular}{ll}
\hline \multicolumn{1}{c}{ Kritērijs } & \multicolumn{1}{c}{ Uzdevuma raksturojums } \\
\hline Izpratne disciplīnā ar fokusu uz būtisko & Augsta. Nezināmais lielums vienādībā \\
\hline $\begin{array}{l}\text { Starpdisciplinaritāte (pārnesums, } \\
\text { integritāte, autentiskums) }\end{array}$ & $\begin{array}{l}\text { Pārnesuma nepieciešamība - matemātisko } \\
\text { pamatprasmju lietošana jaunā situācijā }\end{array}$ \\
\hline Prasmes, kas tiek mērītas & $\begin{array}{l}\text { Teksta izpratne, stratēḡijas izvēle nezināma } \\
\text { saskaitāmā aprēḳināšanai, ja summa zināma; } \\
\text { skaitlisku darbību izpilde }\end{array}$ \\
\hline Kognitīvās darbības dziḷums & Vidējs - SOLO III līmenis \\
\hline Metakognitīvā darbība. & Nav \\
\hline Atbilžu, risināšanas stratēǵiju variativitāte & Pareiza viena atbilde, vairāki risinājuma ceḷi \\
\hline Vērtēšanas kritēriji & $\begin{array}{l}\text { Neatbilstoši, iegūst informāciju tikai par to, vai } \\
\text { formālā atbilde ir pareiza }\end{array}$ \\
\hline
\end{tabular}


Uzdevumam ir pilnveidošanas iespējas. Ir potenciāls pārliecināties, kā skolēns apzinās nepieciešamās prasmes, kā pārvalda paškontroles iespējas. (Skat. piemēru.) Vērtēšanas kritēriji formulējami tā, lai pārbaudītu visas prasmes, tostarp prasmi izveidot stratēgiju, lietot prasmes jaunā situācijā. (Skat. iespējamo vērtēšanas kritēriju piemēru.)

lespējamo vērtēšanas kritēriju piemērs:

- skolēns izmanto tekstā un attēlā doto informāciju (faktu, ka summa ir 33, saskata, kā ši summa veidojas),

- izstrādā stratēgíiju, kā (kādā secībā) iespējams pakāpeniski aizpildīt kvadrātu,

- pareizi izpilda aritmētiskās darbības (saskaitīšanu, atñemšanu) ar skaițliem 20 apjomā.

Saglabājot kopīgo punktu skaitu, katram no šiem kritērijiem var atvēlēt 2 punktus, sīkāk definējot, kāds sniegums atbilst 2, kāds 1 un kāds 0 punktiem.

Lai vērtējot būtu iespējams konstatēt katra kritērija izpildi, nepieciešams arī nedaudz pārformulēt uzdevumu. Piemēram, lai saprastu, vai skolēnam bija stratēgija, kā atbilstoši uzdevuma nosacijumiem veikt prasìto, uzdevumu vajadzētu papildināt: "Iekrāso to rūtiņu, kuru aizpildīji vispirms! Uzraksti, kāpēc tieši to!"

Pārbaudes darbos šobrīd neierasta prakse ir sekot skolēnu metakognitīvajām prasmēm. Aplūkotajam uzdevumam ir arī šāds potenciāls. Piemēram:

- papildinot uzdevumu ar jautājumu: "Kā tu vari pārliecināties, ka kvadrāts aizpildīts pareizi?", skolēns tiek rosināts domāt par paškontroles iespējām; skolotājs var pārliecināties, vai skolēnam ir kāda atbilstoša stratēǵija,

- uzdevumā var būt jautājums: "Kādas prasmes tev bija nepieciešamas, lai veiktu šo uzdevumu?", tādējādi konstatējot, vai skolēns atpazīst, apzinātā līmenī saista uzdevuma izpildes gaitā veiktās darbības,

- var veidot uzdevumu virkni, piemēram, jautājot, kā iepriekšèjā uzdevuma risinājums var palīdzēt izpildīt nākamo:

$8+11+14=\ldots$

$8+13+\ldots=33$

Tātad ir vairākas iespējas pilnveidot uzdevumu, lai tas dotu lielāku, precīzāku informāciju par skolēna sniegumu (skat. piemēru 5. attēlā). 
Tukšajās rūtināās ieraksti skaițus tā, lai triju skaițu summa visos virzienos (gan horizontāli, gan vertikāli, gan pa diagonāli) būtu 33.

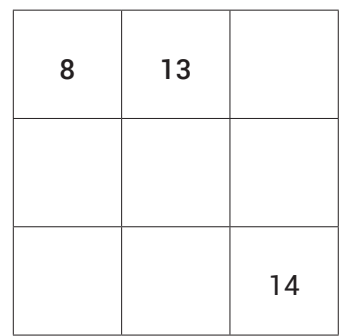

lekrāso to rūtinu, kuru aizpildīji vispirms! Uzraksti, kāpēc tieši to! Kādas prasmes Tev bija nepieciešamas, lai veiktu šo uzdevumu?

5. attēls. Matemātikas uzdevuma jaunā redakcija

Otrs piemērs, kura potenciāls analizēts 12. tabulā, ir uzdevums no piloteksāmena k̦īmijā 2016. gadā (skat. 6. attēlu). Šì uzdevuma autoru formulētais vērtēšanas kritērijs: Izmantojot tabulā doto informāciju, uzraksta vienu iemeslu, kāpēc aprikozēs, kuras tiek konservētas pēc "sēra dedzināšanas" metodes, bieži tiek pārsniegta sēra (IV) oksīda pielaujamā norma.

\section{6. uzdevums (4 punkti)}

Pēdējos gados ir veikti vairāki nozīmīgi pētījumi par aprikozēm. Aprikozes satur lielu daudzumu $\beta$-karotīnus. Aprikozēm ir īss uzglabāšanas laiks. Lai to pagaronātu, izmanto daudzveidīgas konservēšanas metodes: saldēšanu, fasēšanu hermētiski noslēgtos iepakojumos, žāvēšanu ar un bez sēra(IV) oksīda. Sēra(IV) oksīds saglabā aprikožu dabisko dzelteno krāsu un pasargā no pūšanas. Izlasi trīs aprikožu konservēšanas metolzu aprakstus!

Tabula

Aprikožu konservēšanas metožu apraksti

\begin{tabular}{|c|c|c|}
\hline Sēra dedzināšana & $\begin{array}{c}\text { Sašḳidrināta sēra(IV) oksīda } \\
\text { izmantošana }\end{array}$ & $\begin{array}{c}\text { Nātrija disulfīta } \mathrm{Na}_{2} \mathrm{~S}_{2} \mathrm{O}_{5} \\
\text { šḳīduma izmantošana }\end{array}$ \\
\hline $\begin{array}{l}\text { Telpā aprikozes izvieto vienā } \\
\text { slānī. Telpā sadedzina sēru. } \\
\text { Pēc sēra sadegšanas telpa tiek } \\
\text { slēgta un aprikozes tiek izturētas } \\
12 \text { stundas sēra(IV) oksīda gāzē. } \\
\text { Izmantojot šo metodi, bieži tiek } \\
\text { pārsniegta sēra(IV) oksīda pie-- } \\
\text { l̦aujamā norma } 2000 \text { mg/kg. }\end{array}$ & $\begin{array}{l}\text { Telpā aprikozes izvieto vienā } \\
\text { slānī. Aprikozes iztur } 3,5 \\
\text { stundas telpā, kurā ir precīza } \\
\text { sēra(IV) oksīda koncentrācija. } \\
\text { To nodrošina, iztvaicējot } \\
\text { precīzu sašk̦idrināta sēra(IV) } \\
\text { oksīda masu. Telpā izmanto } \\
\text { ventilatorus un silda gaisu. }\end{array}$ & $\begin{array}{l}\text { Pagatavo precīzas } \\
\text { koncentrācijas } \\
\text { nātrija škīīumu, kurā } \\
35 \text { minūtes mērcē } \\
\text { aprikozes. }\end{array}$ \\
\hline
\end{tabular}

6.1. Izmantojot tabulā doto informāciju, uzraksti vienu iemeslu, kāpēc aprikozēs, kuras konservē pēc "Sēra dedzināšanas" metodes, bieži tiek pārsniegta sēra(IV) oksīda pielaujamā norma!

6. attēls. Piloteksāmena uzdevums k̦īmijā 12. klasei (VISC, 2016) 
12. tabula. Uzdevuma k̦īmijā analīze

\begin{tabular}{ll}
\hline \multicolumn{1}{c}{ Kritērijs } & \multicolumn{1}{c}{ Uzdevuma raksturojums } \\
\hline Izpratne disciplīnā ar fokusu uz būtisko & Zema \\
\hline $\begin{array}{l}\text { Starpdisciplinaritāte (pārnesums, integritāte, } \\
\text { autentiskums) }\end{array}$ & Autentisks konteksts \\
\hline Prasmes, kas tiek mērītas & Viena atbilstoša fakta atrašana tekstā \\
\hline Kognitīvās darbības dziḷums & Zems \\
\hline Metakognitīvā darbība & Nav \\
\hline Atbilžu, risināšanas stratēḡiju variativitāte & lespējamas dažādas atbildes \\
\hline Vērtēšanas kritēriji & Formāli - pareizi/nepareizi \\
\hline
\end{tabular}

Pilnveidojot uzdevumu, nepieciešams padziḷināt izpratni par ķīmisko reakciju norises apstākḷiem un faktoriem, kas to ietekmē; pārveidot uzdevumu tā, lai būtu iespējams mērìt prasmi argumentēt un atbilstoši pārveidot vērtēšanas kritērijus kompleksa snieguma mērī̌sanai.

Analizējot uzdevumu un skolēnu darbus, rodas jautājums - kas īsti tiek vērtēts? Kādas zināšanas, prasmes parāda skolēns, rakstot šo vienu iemeslu, izmantojot uzdevuma tekstu gandrīz pus lapas (A4) apjomā? Analīze rāda, ka tiek sagaidītas un akceptētas visai primitīvas skolēnu atbildes:

- viss $\mathrm{SO}_{2}$ nosēžas uz aprikozēm, jo tas ir smagāks par gaisu,

- aprikožu uzglabāšana 12 stundas slēgtā telpā liecina par to, ka sēra (IV) piel̦aujamā norma nav kontrolējama, tāpēc tā tiek pārsniegta,

- šajā konservēšanas metodē grūti kontrolēt sēra degšanas temperatūru, skābekḷa koncentrāciju gaisā, sēra (IV) oksīda vienmērīgu koncentrāciju visā telpā; grūti kontrolèt, vai sērs ir pilnīgi sadedzis,

- jo telpa pēc sēra sadegšanas tiek slēgta,

- tāpēc, ka tās ilgu laiku pavada sēra ietekmē.

Ja uzskatām, ka mācīšanās rezultāts ir prasmes, tad šis uzdevums ir kā neizmantotā iespēja. Pārformulējot uzdevumu, tekstā iekḷautā informācija dotu iespēju iegūt pilnīgi citu ainu par skolēna sniegumu. Skolēnam būtu jāprasa pamatot, kāpēc ar šo metodi tiek pārsniegta piel̦aujamā norma, jeb izveidot apgalvojumu, kas ietver to faktoru analīzi, no kā ir atkarīgs rezultāts. Faktori atrodami esošajā tekstā, tie tiek pamatoti ar datiem. Pamatošanas prasmes vērtēšanas līmeņi aprakstīti 13. tabulā. 
Lai skolēns tiktu pie atbildes:

- jāizlasa trīs nelieli, vienkārši teksti, kas doti uzdevuma tabulā "Aprikožu konservēšanas metožu apraksti”, kuros ir aprakstītas procedūras, atrodami faktori,

- jāsaprot teksta jēga, jāatrod faktori - cik biezi saliktas, cik stundu turētas, kaitīgo vielu koncentrācija, kas vēl papildus tiek darīts,

- jāveic salīdzināšana, spriežot pēc būtiskām pazīmēm,

- jāuzraksta pamatojums.

13. tabula. Līmeṇu apraksts pamatošanas prasmes vērtēšanai

\begin{tabular}{ll}
\hline 0 & Nav apgalvojuma formā, nesatur faktus no dotās informācijas. \\
\hline 1 & $\begin{array}{l}\text { Pamatojumam ir ar būtiskas nepilnības, t. i., tekstā atrasti fakti; tekstā atrasts viens } \\
\text { faktors no vairākiem (cik bieži saliktas; cik stundu turētas - laiks; koncentrācija - } \\
\text { ir/nav kontrolējama; kas vēl papildus tiek darīts...). Pamatojums nav izveidots. }\end{array}$ \\
\hline 2 & Ir pamatojums, tas satur 1-2 tekstā atrastus ietekmējošos faktorus. \\
\hline 3 & $\begin{array}{l}\text { Pamatojums ir piln̄̄gs un argumentēts, tas satur 1-2 tekstā atrastus faktorus, kas } \\
\text { balstīti faktos (virsmas laukums - cik biezi saliktas; laiks - cik stundu turētas); } \\
\text { koncentrācija; kas vēl papildus tiek darīts, t. i., katram faktoram nosaukts atbilstošs } \\
\text { fakts no teksta. }\end{array}$ \\
\hline 4 & $\begin{array}{l}\text { Apgalvojums ir pilnīgs un pamatots - ietverti visi tekstā atrodamie faktori, tas ir } \\
\text { sasaistīts ar zināšanām par } \mathrm{SO}_{2} \text { relatīvo blīvumu pret gaisu u. c. }\end{array}$ \\
\hline
\end{tabular}

Ietverot minētās uzdevuma pilnveidošanas iespējas, 7. attēlā redzama uzdevuma jaunā redakcija.

Būtu nepieciešams precīzāk diagnosticēt tieši kompleksu prasmju apguvi, salīdzinot rezultātus ar datiem par mācību procesā notiekošo, lai varētu precizēt iespējamos situācijas uzlabošanas risinājumus. Ieteikums sekot kritērijiem, kas raksturo labu kompleksu uzdevumu, gan to izstrādājot, gan atlasot, gan pilnveidojot uzdevumus, kuri tiek iekḷauti valsts līmeņa pārbaudes darbos.

Turpinot diskusiju, analīzē konstatēts, ka zināšanu un izpratnes par procesiem, parādībām dabā, specifisku prasmju apguves mērījumi nedod iespēju iegūt drošu atbildi par skolēna sniegumu katrā no mācỉbu satura laukiem, jo tas notiek fragmentāri - darbā iekḷautie testelementi aptver nelielu dalı no satura kopumā. Diskutējams ir darbos ietverto jautājumu būtiskums. Tas pats attiecas uz skolēnu pētnieciskās darbības prasmēm. Šobrīd tiek radīti diagnosticējošie un pārbaudes darbi ar milzīgu apjomu, bet iegūtā informācija par skolēnu sniegumu, kas ir ticama un droša, ir neliela. Vienā darbā kvalitatīvi nav iespējams izmērìt visu - aptvert gan priekšmetu specifisko saturu, gan vispārēju būtisku prasmju diagnosticēšanu. 


\section{6. uzdevums (4 punkti)}

Pēdējos gados ir veikti vairāki nozīmīgi pētījumi par aprikozēm. Aprikozes satur lielu daudzumu bēta-karotīna. Aprikozēm ir īss uzglabāšanas ilgums. Lai to pagarinātu, izmanto daudzveidīgas konservēšanas metodes: saldēšanu, fasēšanu hermētiski noslēgtos iepakojumos, žāvēšanu ar un bez sēra (IV) oksīda. Sēra (IV) oksīds saglabā aprikožu dabisko dzelteno krāsu un pasargā no pūšanas. Izlasi trīs aprikožu konservēšanas metožu aprakstus!

Tabula

Aprikožu konservēšanas metožu apraksti

\begin{tabular}{|c|c|c|}
\hline Sēra dedzināšana & $\begin{array}{c}\text { Sašḳidrināta sēra (IV) oksīda } \\
\text { izmantošana }\end{array}$ & $\begin{array}{c}\text { Nātrija disulfīta } \mathrm{Na}_{2} \mathrm{~S}_{2} \mathrm{O}_{5} \\
\text { šḳīduma izmantošana }\end{array}$ \\
\hline $\begin{array}{l}\text { Telpā aprikozes izvieto vienā } \\
\text { slānī. Telpā sadedzina sēru. } \\
\text { Pēc sēra sadegšanas telpa tiek } \\
\text { slēgta un aprikozes tiek izturētas } \\
12 \text { stundas sēra (IV) oksīda } \\
\text { gāzē. Izmantojot šo metodi, bieži } \\
\text { tiek pārsniegta sēra (IV) oksīda } \\
\text { pieḷaujamā norma } 2000 \text { mg/kg. }\end{array}$ & $\begin{array}{l}\text { Telpā aprikozes izvieto vienā } \\
\text { slānī. Aprikozes iztur } 3,5 \\
\text { stundas telpā, kurā ir precīza } \\
\text { sēra (IV) oksīda koncentrācija. } \\
\text { To nodrošina, iztvaicējot } \\
\text { precīzu sašk̦idrināta sēra (IV) } \\
\text { oksīda masu. Telpā izmanto } \\
\text { ventilatorus un silda gaisu. }\end{array}$ & $\begin{array}{l}\text { Pagatavo precīzas } \\
\text { koncentrācijas } \\
\text { nātrija škīldumu, kurā } \\
35 \text { minūtes mērcē } \\
\text { aprikozes. }\end{array}$ \\
\hline
\end{tabular}

Pamato, kāpēc, izmantojot aprikožu konservēšanai sēra dedzināšanas metodi, bieži tiek pārsniegta pielaujamā sēra (IV) oksīda norma! Izmanto tekstā un tabulā doto informāciju, nosakot un analizējot faktorus, kas ietekmē rezultātu. (Snieguma aprakstu skat. iepriekš.)

7. attēls. Uzdevuma kīimijā jaunā redakcija

Darbu kopējais apjoms diagnosticējošajos un pārbaudes darbos ir liels, piemēram, dabaszinībās 6. klasei 2017. gada darba apjoms ir 7 lpp., 9. klasei - 8 lpp.; 9. klasei 2016. gadā - pat 12 lappuses. Darba izpildes laiks ir 80 minūtes. Darba lielais apjoms skolēniem ar sliktāku lasītprasmi varētu radīt ierobežojumus dabaszinātniskās izpratības un prasmju demonstrēšanā.

Ne vienmēr tekstuālā un vizuālā informācija ir noderīga, lai veiktu uzdevumu. Ir gadijjumi, kad autori uzdevuma formulējumā norāda uz nepieciešamību izmantot doto informāciju, bet tā nepalīdz veidot skolēnam atbildi - faktiski tiek pārbaudìtas skolēna zināšanas, piemēram, 13. un 14. uzdevumā 2017. gadā diagnosticējošā darbā dabaszinībās 6. klasei. Kā labu piemēru, kur tekstuālā un vizuālā informācija ir būtiska - nepieciešama, izmantojama uzdevuma veikšanai, var minēt 1.3., 8. un 10. uzdevumu 2017. gada diagnosticējošajā darbā dabaszinātnēs 9. klasei. 2017. gadā diagnosticējošajā darbā atškirīibā no iepriekšējā gada vērojama pozitīva virzība: izmantotie teksti nav ḷoti apjomīgi, bet dotā informācija ir ietilpìga. Piemēram, 9. uzdevumā šķietami vienkāršajā attēlā jānolasa informācija gan par to, ka tas ir lēciena sākums, gan tas, ka abi attēlotie spēki ir vienādi, kaut arī šiem abiem aspektiem vārdiskajā tekstā netiek pievērsta îpaša uzmanība. 
Analīzes veicēju formulētie uzdevumu indikatori daudzos gadījumos nesakrìt ar uzdevumu autoru dotajiem vērtēšanas kritērijiem ${ }^{8}$ (skat. piemērus 14. tabulā). Iemesls varētu būt formāla pieeja - nepieciešamajiem/izvēlētajiem indikatoriem, iespējams, piekārtoti uzdevumi, kas indikatoram atbilst nepilnīgi. Uzdevums nav izvērtēts pēc būtības, precīzi aprakstot konkrētā uzdevuma izpildei nepieciešamās zināšanas un prasmes.

14. tabula. Atškirīibas indikatoru formulējumos 2017. gada diagnosticējošajam darbam dabaszinātnēs 9 . klasei

\begin{tabular}{lll}
\hline Uzd. & \multicolumn{1}{c}{ Autoru formulētais indikators } & Analīzes ekspertu formulētais indikators \\
\hline 3.2. & $\begin{array}{l}\text { Skaidro novērojumu, izmantojot } \\
\text { informāciju un pieredzi }\end{array}$ & $\begin{array}{l}\text { Zina, ka, temperatūrai palielinoties, notiek } \\
\text { iztvaikošana, veidojas burbuḷi - ūdens } \\
\text { gāzveida stāvoklī }\end{array}$ \\
\hline 8.1. & Izvēlas darba piederumus & $\begin{array}{l}\text { No teksta nosaka izvēlēto neatkarīgo } \\
\text { main̄̄go; zina, ka vienlaikus nedrīkst mainīt } \\
\text { divus lielumus; attēlā un atbilžu variantos } \\
\text { atrod atbilstošo situāciju }\end{array}$ \\
& & $\begin{array}{l}\text { Zina, ka sēnes un monēras noārda } \\
\text { organiskās vielas }\end{array}$ \\
\hline 15.3. & $\begin{array}{l}\text { Izspriež, kuras valsts pārstāvji } \\
\text { nodrošina vielu noārdīšanu } \\
\text { ekosistēmā }\end{array}$ & \\
\hline
\end{tabular}

Ir daudz uzdevumu, kuros nepieciešama prasme strādāt ar informāciju. Rodas jautājums, vai tas darīts apzināti. Turpmāk, izvēloties indikatoram atbilstošu uzdevumu un/vai otrādi - nosakot indikatoru (ko mēra konkrētais uzdevums), detalizēti jāizvērtē šì atbilstība, kas palīdzēs saprast uzdevuma izmantošanas mērḳi - vai primārais ir mērìt izpratni par procesiem, parādībām, pētniecību vai tekstpratību.

Konstatējama neatbilstība arī starp ekspertu noteikto un pārbaudes darbu autoru definēto uzdevumu kognitīvo dziḷumu, kam pamatā ir atškirīga metodologiija. Valsts mēroga pārbaudes un diagnosticējošos darbos tradicionāli tiek piedāvāts skolēnu izziņas darbības sniegumu aplūkot trīs līmeņos: 1. līmenis iegaumēšana un izpratne; 2. līmenis - zināšanu un prasmju lietošana; 3. līmenis - analīze un produktīvā darbība. ${ }^{9}$

Teorijā šim nolūkam tiek izmantotas dažādas taksonomijas (Blūma, Stouna, SOLO u. c.), OECD PISA testu ietvaram definēti līmen̦i - zems, vidējs un augsts,

8 Pārbaudes un diagnosticējošie darbi. Pieejams: http://visc.gov.lv/vispizglitiba/eksameni/ uzdevumi.shtml (aplūkots 13.02.2018.).

9 VISC piedāvātie pārbaudes un diagnosticējošie darbi. Pieejams: http://visc.gov.lv/vispizglitiba/ eksameni/uzdevumi.shtml (aplūkots 13.02.2018.). 
kas tālāk iedalīti sešos līmeņos, pirmo iedalot vēl la un $1 b$, kā arī paredzot, ka sniegums var būt zem 1. lìmeņa. Lai būtu iespējams salīdzināt kognitīvās darbības dziļumu dažādos pārbaudes darbos, kā arī mācību stundās, iespējama dažādo instrumentu pielīdzināšana, nosakot to samērojamību.

Analīzi veicot, izmantota SOLO taksonomija, kas palīdz konstatēt atšķirību starp augstākajiem līmen̦iem.

Turpmāk apsverama vēl precīzākas (Pannzion, \& Pegg, 2003) aprakstītās pilnveidotās SOLO taksonomijas izmantošana, skolēna sniegumu aplūkojot divos lokos. Katrs loks ietver trīs līmeņus atbilstoši klasiskajai SOLO taksonomijai. Tādējādi detalizētāk tiktu izzināta citu valstu pieredze makrolīmeņa darbu veidošanā un vērtēšanā.

Aplūkojams vēl ir viens aspekts, kas saistìts ar kognitīvās darbïbas līmeni valsts mēroga pārbaudes darbos. Visu pārbaudes darbu programmās norādīts katram izziņas darbības līmenim atbilstošo uzdevumu ìpatsvars darbā procentos (skat. 15. tabulu).

15. tabula. VISC norādītais 2017. gada darbos iekḷauto testelementu sadalījums pa izziṇas līmen,iem \%

\begin{tabular}{cccccc}
\hline & $\begin{array}{c}\text { Matemātika } \\
\text { 3. kl. }\end{array}$ & $\begin{array}{c}\text { Matemātika } \\
\text { 6. kl. }\end{array}$ & $\begin{array}{c}\text { Matemātika } \\
\text { 9. kl. }\end{array}$ & $\begin{array}{c}\text { Dabaszin̄ibas } \\
\text { 6. kl. }\end{array}$ & $\begin{array}{c}\text { Dabaszinātnes } \\
\text { 9. kl. }\end{array}$ \\
\hline I & $28-29$ & $16-17$ & $22-24$ & $40-45$ & $15-20$ \\
\hline II & $45-46$ & $67-68$ & $64-66$ & $45-50$ & $55-60$ \\
\hline III & $24-25$ & $15-16$ & $9-11$ & $13-18$ & $20-25$ \\
\hline
\end{tabular}

Rodas jautājums, kādi apsvērumi ir šādas pieejas pamatā - būtiskām atšḳirībām katram kognitīvās darbības līmenim atbilstošo uzdevumu īpatsvarā gan starp mācību priekšmetiem, gan starp klasēm jau pārbaudes darbu programmu līmenì.

Kā iepriekš minēts (skat. 15. tabulu), augsta līmeņa uzdevumu darbos faktiski nav. Šì pretruna skolotājiem var radìt maldīgu priekšstatu par uzdevumu kognitīvo dziḷumu. OECD PISA testā 2015 zema kognitīva līmeņa uzdevumu kategorijā ietilpa $30 \%$ uzdevumu, vidēja $-62 \%$, augsta $-8 \% .^{10}$

LU SIIC iepriekš veiktie pētījumi (France, Namsone, Čakāne, Dzērve, \& Vilciņš, 2016) rāda, ka mācību procesā ir zema kognitīvā aktivitāte. Viens no iemesliem varētu būt valsts mēroga pārbaudes darbi, jo vairāki pētỉjumi (piemēram,

${ }^{10}$ OECD (2016). PISA 2015 Results (Volume I): Excellence and Equity in Education, PISA, OECD Publishing, Paris. Pieejams: http://dx.doi.org/10.1787/9789264266490-en (aplūkots 12.02.2018.). 
Millar, 2013) liecina, ka skolotāji, izvēloties mācību procesā izmantojamos uzdevumus, lielā mērā orientējas uz to, kas tiek sagaidīts valsts līmeņa pārbaudes darbos. Tik liels zema kognitīvā līmeņa uzdevumu pārsvars valsts pārbaudes darbos, kāds tas ir šobrīd, neveicina produktīvu mācību aktivitāšu skaita palielināšanos mācību stundās. Vienlaikus jāatzīmē pozitīva tendence - darbos tiek iekḷauti atsevišḳi uzdevumi, kuros jādemonstrē augsta līmeṇa kognitīvā darbïba. Taču joprojām augstam kognitīvajam līmenim atbilstošu uzdevumu vispār nav dabaszinībās 6. klasei, matemātikā 6. un 9. klasei. Otrs iemesls, kāpēc jāpalielinās to uzdevumu skaitam, kas sagaida skolēna darbību dziḷākā kognitīvajā līmenī (SOLO taksonomijas 3. un 4. līmenis), - lai būtu iespējams precīzāk noteikt skolēnu spēju spektru.

Iekḷautie uzdevumi vērtēšanas darbos var padarìt mācǐšanos efektīvāku, bet ir arī riski. Piemēram, dabaszinātņu jomā atkarībā no tā, kādi uzdevumi tiek iekḷauti, dabaszinātniskās izpratības veidošanās var tikt attīstīta vai bremzēta. Citi (Britton, 2007) atzīmē, ka, iekḷaujot obligātos pārbaudījumus tekstpratībā un matemātikā, novērota tendence, ka skolās tiek samazināta uzmanība dabaszinātṇu jomai. Ir pierādijjumi, ka skolotāji veic izmaiņas mācību saturā un metodēs, vadoties tieši no uzdevumiem makrolīmeņa vērtēšanas darbos. Ja vērtēšanas darbā dominē atbilžu izvēḷu uzdevumi, tad arī mācišsanas procesā parādās liels skaits tieši šāda tipa uzdevumu. Un otrādi - pieaugot atvērto, strukturēto atbilžu skaitam, kuru vērtēšanai izmanto rubrikas, pieaug arī līdzīgu darbu skaits mācīšanās procesā (Britton, 2007; Millar, 2013). Vērtēšanas darbos makrolīmenī ir liels skaits atbilžu izvēḷ uzdevumu un îso atbilžu uzdevumu, jo tādi testelementi ir vienkāršāk un lētāk pārbaudāmi un vieglāk administrējami nekā atvērti, "esejas" tipa uzdevumi.

Šobrīd Latvijā summatīiā vērtēšana matemātikā un dabaszinātnēs tiek veikta, izmantojot rakstisku pārbaudes darbu, kas neḷauj pilnībā novērtēt skolēnu prasmes. Jāapsver iespēja summatīvajai vērtēšanai izmantot dažādas formas, kombinētus vērtēšanas rīkus, ne tikai rakstiskos pārbaudes darbus. Vērtēšanu vēlams îstenot, kombinējot skolotāju vērtējumus ar centralizētajām procedūrām un ārējiem vērtētājiem (Darling-Hammond, \& Adamson, 2010), vienlaikus paredzot atbalstu skolotājiem, lai panāktu vērtētāju vienādu izpratni par snieguma kvalitāti (Stiggins, Arter, Chappuis, \& Chappius, 2004). Izmantojot IT, iespējams precīzāk konstatēt būtisku pamatprasmju līmeni un piedāvāt skolēnam nākamo uzdevumu atbilstoši iepriekšèjā uzdevumā parādītajam prasmju snieguma limenim.

Sabalansēta uzdevumu grūtības pakāpe ir viens no kvalitatīva pārbaudes/ vērtēšanas darba kritērijiem. Tā vistiešākajā veidā var ietekmēt skolēnu rezultātus, tāpēc jāskata kontekstā ar šiem uzdevumu raksturojošiem rādìtajiem. Piemēram, 2017. gadā diagnosticējošajā darbā dabaszinātnēs 9. klasei ir 6 testelementi, kuru grūtības pakāpe mazāka par 0,25 (tie izrādījušies par grūtu konkrētajai 
skolēnu grupai). Nav neviena uzdevuma, kurš (atbilstoši pārbaudes darbu izveides teorijai) būtu šai skolēnu grupai par vieglu. Arī pašu vieglāko testelementu pareizi izpildījuši tikai 75\% skolēnu. Savukārt 6. klases darbs uzrāda pretēju ainu - liela daļa uzdevumu atbilstoši IRT Raša modelim ir par vieglu. Tas nozīmē, ka tas, cik labi vai slikti izrādījušies skolēnu rezultāti darbā kopumā un/ vai atsevišķos uzdevumos, nav drošs pamats, lai spriestu par skolēnu patiesajam prasmēm, iespējamo sniegumu. Nepieciešama ne tikai rūpīga uzdevumu izstrāde, bet arī uzdevumu raksturojošo parametru definēšana. Līdztekus pārbaudes darbu izstrādei jāapsver iespējas pilnveidot arī ekspertēšanas un aprobācijas procesu, detalizēti analizējot iegūto informāciju par uzdevumiem.

Šobrīd esošajiem diagnosticējošajiem darbiem ir neskaidrs fokuss (ko tie pretendē mērìt), bet vērtěšanas kritēriji nepalīdz veikt diagnosticējošo funkciju - tie nedod atbildi, ko tieši skolēns prot, ko neprot, kāds ir kḷūdu cēlonis. Izņēmums ir diagnosticējošais darbs matemātikā 8. klasei, kas pretendē mērìt skolēnu specifiskās matemātiskās prasmes konkrēta satura temata ietvaros. Šajos darbos savukārt pietrūkst apjomīgāku problēmuzdevumu, kas mēra kompleksu sniegumu, prasmju lietojumu praktiskās situācijās. Darbs jāveido precīzā atbilstībā tā mērḳim, skolai un skolotājiem jāsaņem turpmākās darbības plānošanai izmantojama informācija par rezultātiem. Izvirzot prioritāro mērḳi - sekmēt skolas atbildību, skolēnu rezultātiem vērtēšanās darbā nevajadzētu kalpot par vienīgajiem datiem, kuri tiek interpretēti, lai izdarītu secinājumus par skolas līmeni. Nepieciešams arī pārskatìt tradicionālo pien̦ēmumu, ka par izglìības sistēmu ir iespējams iegūt datus, piedaloties visiem skolēniem (Black, 1990). Vērtējot skolēnu reprezentatīvo kopu sasniegumus, pietiek ar daudz mazāku skolēnu skaitu, toties ir iespēja veikt padziḷinātu analīzi.

\section{Kāda saistība ir makrolīmeṇa darbiem ar nepieciešamajiem uzlabojumiem mācīšanās procesā skolā}

Kā skolēniem izdodas vienā priekšmetā apgūto lietot citos mācību priekšmetos, un kas būtu darāms, lai skolēnu sniegums būtu labāks? Viens no 21. gadsimta atbilstošas mācišanās rezultātiem ir prasme lietot apgūtās zināšanas un prasmes dažādā kontekstā. Tie var būt gan jauni konkrētās zinātnes, gan sadzīviski, ar reālo dzīvi saitīti konteksti, gan no citām zinātnēm, jomām, starpdisciplināri. Visos analizētajos dabaszinātņu darbos iekḷauti uzdevumi, kuru izpildei nepieciešamas prasmes, kuras sākotnēji tiek mācìtas matemātikā. (Pārbaudes darbos matemātikā nav uzdevumu, kuru veikšanai būtisks būtu citos mācību 
priekšmetos apgūtais.) Visos šajos uzdevumos trīs gadu laikā skolēnu rezultāti ir lıoti zemi. Problēma par iepriekš apgūto prasmju lietojumu citos mācību priekšmetos analizēta arī Latvijā (France, et al. 2016).

Uz matemātikas lietojumu dabaszinātṇu kontekstā, piemēram, 2015. gadā attiecināmi trīs testelementi - 5.2., 6.2. un 10.4. To grūtības pakāpes atbilstoši ir 0,36; 0,22 un 0,17 . Salīdzinot ar kopējiem rezultātiem (darba grūtības pakāpe $0,43)$, redzams, ka šie trīs uzdevumi skolēniem ir izrādījušies pārāk grūti, viṇu prasmes atrisināt šos uzdevumus vērtējamas kā kritiskas. Neraugoties uz to, ka šo uzdevumu grūtības pakāpe izrādijusies ḷoti augsta, uzdevumi ir tieši par to, ko vēlamies, - lai vairums skolēnu spētu lietot matemātiskās pamatprasmes dažādās, ne tikai tipveida situācijās, tostarp reālās dzīves situācijās.

Piemērs 10.4. Aprēķini vajadzīgo kristāliskā nātrija hlorìda masu, lai pagatavotu $500 \mathrm{~g}$ fiziologiiskā šķiduma - 0,9\% NaCl šķìdumu. Parādi risinājumu!

Veiksmīgai uzdevuma izpildei, lasot tekstu (reālās dzīves kontekstu), jāsaprot jēga, ka nepieciešamā vielas masa ir daḷa no veselā - no šḳīduma masas; jāsaprot, kas ir \%, kas ir daļa no veselā un kas ir procenta daļa; jāprot aprēķināt daļas vērtību, lietojot algoritmu, spriežot; jāprot izpildìt darbïbas ar skaitḷiem.

Šì uzdevuma rezultāti ir vissliktākie, kaut gan konkrētā satura mācǐšana matemātikā sākas ar izpratnes par dạ̦ām veidošanu 3. un 4. klasē, turpinās 5. un 6. klasē, kad apgūst visu veidu daḷu un procentu aprēkinus; procentu aprēḳināšana tiek mācìta arī kịmijā 8. klasē. Dati rāda - no skolēnu grupas ar augstiem sasniegumiem darbā kopumā šo uzdevumu veikuši tikai $46 \%$, no grupas ar zemiem sasniegumiem - 6\%. Tā kā uzdevums gan no matemātikas, gan ķìmijas mācīšanās aspekta nav tipveida situācija, iespējams, ka dạ̣a skolēnu to nemègina risināt.

Uz šo problēmu norādīts metodiskajos materiālos "Diagnosticējošais darbs dabaszinātnēs 9. klasei 2014./2015. mācību gadā: rezultātu analīze un ieteikumi” un "Diagnosticējošais darbs dabaszinātnēs 9. klasei 2015./2016. mācību gadā: rezultātu analīze un ieteikumi” ${ }^{11}$, taču nākamajos divos mācību gados nav izdevies panākt situācijas uzlabošanos.

Tajā pašā laikā vērojams, ka atseviškiiem skolēniem ir potenciāls šādu uzdevumu veikšanai: vinịi spēj veidot pārnesumu - izmantot citos mācību priekšmetos iepriekš mācìto. Iepazisstoties ar skolēnu darbiem, kuri šo uzdevumu ir risinājuši, redzams, ka tikai daži skolēni ir risinājuši uzdevumu, izmantojot ķīmijā

${ }^{11}$ Diagnosticējošais darbs dabaszinātnēs 9. klasei 2014./2015. mācību gadā: rezultātu analīze un ieteikumi. Pieejams: http://visc.gov.lv/vispizglitiba/eksameni/dokumenti/metmat/2014_2015_ ddarbs_dabzin_9kl_analize.pdf (aplūkots 13.02.2018.).

Diagnosticējošais darbs dabaszinātnēs 9. klasei 2015./2016. mācību gadā: rezultātu analīze un ieteikumi. Pieejams: http://visc.gov.lv/vispizglitiba/eksameni/dokumenti/metmat/2015_2016_ ddarbs_dabzin_9kl_analize.pdf (aplūkots 13.02.2018.). 
piedāvāto formulu un atbilstošu risinājuma pierakstu. Skolēni izmanto pārsvarā matemātikā apgūto, izmantojot dažādus paņēmienus:

- atrisinājuma gaitā tiek aprēķināta un tālāk izmantota $1 \%$ vērtỉba,

- skolēni uzreiz aprēķina $0,9 \%$ no šķīduma masas, pārejot uz reizinājumu $(0,9 \%$ no $500=0,009 \cdot 500)$,

- tiek izmantota proporcionalitāte spriežot,

- lieto formulu proporcijas nezināmā locekḷa aprēḳināšanai.

Konstatējot, ka skolēni nespēj izmantot uzdevumā daudzus gadus mācību procesā lietotu algoritmu, iezīmējas nepieciešamība mācību procesā konsekventi noskaidrot skolēnu iepriekšējo pieredzi un balstîties uz to, dažādot uzdevumu kontekstu gan dabaszinātṇu, gan matemātikas stundās, apzināti mācìt skolēniem pārnesuma veidošanu - atpazìt situācijas, paṇēmienus, vairāk izmantot uzdevumus ar atbilžu un risināšanas pañēmienu/stratēgiju variativitāti. Ja mācību stundās apzinātā līmenī tiek mācīts šo pārnesumu veidot, to skolēnu skaits, kas spēj rīkoties jaunā situācijā, varētu kḷūt lielāks, jo kopumā skolēnu sniegums šāda veida uzdevumos ir loti zems. Nepieciešams skaidri apzināties, kuri uzdevumi darbā pārbauda skolēnu prasmi rīkoties jaunā situācijā, lai nepārvērstu tos par vēl vienu tipveida uzdevumu, ko nepieciešams apgūt.

Aktualizējas dažādu mācību priekšmetu/jomu skolotāju sadarbības nozīme, lai palīdzētu skolēnam veidot pārnesumu, vingrināties dažādā kontekstā.

Par skolēnu prasmēm darbā ar informāciju ir vēl kāda iespējama problēma. Skolēni pietiekami labi veic uzdevumus, ja visa nepieciešamā informācija ir vienkopus konkrētā uzdevuma formulējumā. Ja uzdevums ir strukturēts (satur vairākus testelementus) un informācija atbildes veidošanai ir meklējama uzdevuma sākuma tekstā vai iepriekšējos testelementos, rezultāti ir daudz sliktāki. Piemēram, 2016. gada dabaszinātņu diagnosticējošajā darbā 9. klasei uzdevumā 5.3. (skat. 8. attēlu) pareizi atbildējuši tikai $20 \%$ skolēnu, lai gan pareizā atbilde atrodama tekstā uzdevuma sākumā.

\section{5. uzdevums (4 punkti)}

Lai izgatavotu maizes mīklu, pavārs samaisa miltus, ūdeni, sāli un raugu. Pēc samaisišsanas maizes mīklu atstāj uz vairākām stundām, lai uzbriest. Rauga sēnes klātbūtnē notiek kịmiskas pārvērtības, kuru laikā miltos esošās organiskās vielas pārvēršas par oglskābo gāzi un spirtu.

5.3. Kura mīklas satāvdaḷ dod oglekla atomus oglskābās gāzes un spirta molekulu veidošanai? Atzīmē vienu atbildi!

A milti

B sāls

C ūdens

D raugs

8. attēls. Diagnosticējošā darba uzdevums dabaszinātnēs 9. klasei (VISC, 2016) 
Atbilstoši lasītprasmes snieguma aprakstam (skat. 9. attēlu) tiek sagaidìts 2. līmeņa sniegums ar prognozējami labāku rezultātu, nekā tas reāli sasniegts. Iespējamais šādas situācijas cēlonis varētu būt tas, ka skolēni mācību procesā katru uzdevumu pieraduši uztvert kā autonomu, viņiem nav pietiekamas pieredzes saistīt un izmantot informāciju, apzināti meklēt saistību starp uzdevumiem un to risinājumiem.

\begin{tabular}{|c|c|c|c|}
\hline \multicolumn{4}{|c|}{ Rubrika: prasme atrast tekstā informāciju } \\
\hline 1 & 2 & 3 & 4 \\
\hline $\begin{array}{l}\text { Atrod/nolasa } \\
\text { tieši izlasāmu } \\
\text { (burtisku) } \\
\text { informāciju } \\
\text { (konkrēta tekstā } \\
\text { atrodama atbilde uz } \\
\text { konkrētu jautājumu; } \\
\text { termins; ...) }\end{array}$ & $\begin{array}{l}\text { Atrod/nolasa } \\
\text { pazīstamu, bet ne } \\
\text { burtiski izlasāmu } \\
\text { informāciju (tekstā } \\
\text { tas pateikts citiem } \\
\text { vārdiem; formulu, } \\
\text { kas atbilst konkrētai } \\
\text { situācijai; ...) }\end{array}$ & $\begin{array}{l}\text { Atrod/nolasa } \\
\text { daḹjii pazīstamu } \\
\text { situāciju (netieši? } \\
\text { formulētu, piemēram, } \\
\text { atslēgas vārdus, kad } \\
\text { jāpieñem lēmums - } \\
\text { ir vai nav atslēgas } \\
\text { vārds) }\end{array}$ & $\begin{array}{l}\text { Atrod/nolasa } \\
\text { meklējamā } \\
\text { informācija } \\
\text { kompleksa (atslēgas } \\
\text { vārdi }+\ldots \text {...) }\end{array}$ \\
\hline $\begin{array}{l}\text { Vienkāršā (pazīstami } \\
\text { vārdi, pazīstams } \\
\text { saturs) neliela } \\
\text { apjoma viena veida } \\
\text { tekstā }\end{array}$ & $\begin{array}{l}\text { Vienkāršā viena } \\
\text { veida tekstā; var } \\
\text { būt vairāki teksti } \\
\text { (fragmenti) }\end{array}$ & $\begin{array}{l}\text { Teksts dots } \\
2 \text { veidos (vienlaikus } \\
\text { teksts, tabula, } \\
\text { shēma, grafiks, } \\
\text { diagramma, ...) } \\
\text { teksts var saturēt } \\
\text { nezināmus } \\
\text { terminus, ... }\end{array}$ & $\begin{array}{l}\text { Kompleksi (vismaz } \\
3 \text { veidos) dotā jaunā } \\
\text { tekstā (konteksts } \\
\text { nezināms), } \\
\text { nepieciešams } \\
\text { izmantot informāciju } \\
\text { no visiem tekstiem }\end{array}$ \\
\hline $\begin{array}{l}\text { Ja lasīšanas } \\
\text { stratēǵija dota }\end{array}$ & $\begin{array}{l}\text { Ja lasīšanasa } \\
\text { stratēǵijija dota }\end{array}$ & $\begin{array}{l}\text { Lietojot viena veida } \\
\text { lasīšanas stratēǵiju }\end{array}$ & $\begin{array}{l}\text { Lietojot dažādas } \\
\text { lasīšanas stratēǵgijas }\end{array}$ \\
\hline
\end{tabular}

9. attēls. Snieguma līmeṇu apraksts par prasmi atrast tekstā informāciju (LU SIIC arhīvs)

Tas, ka arī skolēniem ar augstu akadēmisko sniegumu ir nepietiekami attīstīta tekstpratība, vedina domāt, ka tās ir sekas mācīšanas procesam stundās, kad skolēni neiegūst nepieciešamo pieredzi. Rezultāti trīs gadu posmā uzrāda skolēnu grūtîbas atrast un izmantot dažādā veidā dotu informāciju un aktualizē gan nepieciešamību ar to apzinātāk strādāt mācību stundās, gan skolotāju sadarbības nepieciešamību, lai, plānojot mācību saturu un procesu, atbalstītu skolēnu vajadzības tekstpratības un citu starpdisciplināru prasmju apguvei un pilnveidošanai.

Gan valsts lïmeña darbos, gan PISA pārbaudijumos l,oti mazs ir to skolēnu skaits, kuri uzrāda labu sniegumu uzdevumos, kas prasa dzil̦u domāšanu. Tas vedina domāt par nepietiekamu problēmuzdevumu risināšanas pieredzi. Par saikni starp rezultātu/skolēnu sniegumu vērtēšanas darbos un procesā 
notiekošo - kā notiek mācišana klasē, skat. 2.1. nodạ̦ā, kur aplūkoti mācību stundu vērošanā iegūtie dati. Tie uzrāda, ka tikai aptuveni 1/3 stundu novērojama skolēnu produktīva darbība (Namsone, Čakāne, \& Cirulis, 2017; Volkinsteine, Namsone, \& Cakane 2015; Namsone, \& Cakane, 2015; France, \& Namsone, Čakāne, Dzērve, \& Vilciņš, 2017).

Interpretējot skolēnu rezultātus saistībā ar izziṇas darbības dzilumu, jāṇem vērā, ka atkarībā no tā, ko un kā skolēni ir mācījušies, kādus konkrētus piemērus pildījuši mācību procesa laikā klasē, viens un tas pats uzdevums kādam var izrādīties pazīstama, citam - jauna situācija, kurā ir nepieciešams pašam radīt pārnesumu no citos priekšmetos apgūtā, un tad kognitīvās darbības dziḷums šiem skolēniem var būt augsts.

Skolēnu sniegums uzdevumos, kas mēra pētnieciskās darbības prasmes, liek domāt par to, vai pietiekami liels ir bijis pētniecisku uzdevumu īpatsvars mācību procesa laikā.

Uzdevumi, kurus sāk iekḷaut pārbaudes darbos un atsevišķās mācību grāmatās, ir dzị̄āki, prasa citus kognitīvos rīkus. Jāpalīdz skolotājiem atpazìt šādus uzdevumus, pārveidot tradicionālos, panākot tajos lielāku kognitīvo dziḷumu. Atlasīto skolēnu darbu analīze atklāj problēmas skolēnu snieguma korektā vērtēšanā. Nepieciešams palīdzēt skolotājiem pilnveidot prasmi vērtēt uzdevumus, kuri izmantojami kompleksu prasmju mācǐšanai; prasmi analizēt statistisko informāciju, kas nonāk skolotāja un skolas rīcībā.

\section{Secinājumi}

Makrolīmeņa vērtēěanas darbi nepilnīgi mēra skolēnu izpratni par procesiem un parādībām dabā. Nepieciešams izstrādāt konkrētu, precīzu mērḳu un indikatoru sistēmu, ko tieši katrs darbs mērīs, pamatojot, kāpēc tas ir svarīgi.

Darbi pārsvarā paredz skolēnu darbỉbu zemā kognitīvā līmenī. Veidojot valsts lïmeņa darbu konstruktus, nepieciešams skaidri definēt paredzamos kognitīvos līmeņus un panākt, lai darbā iekḷautie uzdevumi mēra prasmes plānotajā kognitīvajā līmenī, tostarp augstākajā.

Veidojot valsts līmeņa pārbaudes darbus, jāseko mūsdienīga uzdevuma kritērijiem: uzdevumi pārbauda izpratni par atbilstošās zinātnes būtiskākajiem jautājumiem (lielajam idejām); pārbauda ikvienam nozīmīgas prasmes; uzdevumi ir iespējami starpdisciplināri, autentiski (ar reālo dzīvi saistìti), lai skolēni varētu demonstrēt prasmi veidot pārnesumu; ar iespēju demonstrēt dažādu līmeņu, tostarp visaugstākā, kognitīvu darbību; ar iespēju lietot dažādas stratēgeijas; jāsāk iekḷaut uzdevumus, kuri paredz arī metakognitīvu darbību. Vienlaikus pārskatot 
darba apjomu - samazinot uzdevumu skaitu, lai skolēniem pietiktu laika iedziḷināties šajos uzdevumos.

Ja tiek vērtēta uzdevuma izpildes pareizība, nav iespējams spriest par skolēnu prasmēm, prasmju apguves līmeni. Uzdevumos, ar kuriem tiek pārbaudītas prasmes, komplekss sniegums, jāveido snieguma limen,u apraksti, apsverot iespējas izmantot Austrālijas pieredzi (no SOLO taksonomijas atvasinātu pieeju). Tas būtiski, ne tikai lai adekvāti mērītu skolēnu sniegumu, bet arī tāpēc, ka vērtēšanas kritēriji arī ir viens no orientieriem skolotajiem, lai pārskatìtu savu praksi gan mācišanā, gan vērtēšanā skolas līmenī. Īpaši diagnosticējošo darbu gadỉjumā nepieciešams iegūt daudzpusīgāku informāciju par skolēnu stiprajām pusēm un snieguma dimensijām, lai skaidri saprastu, kādi uzlabojumi nepieciešami.

Ir pārskatīta diagnosticējošo darbu loma, statuss - tiem jābūt rīkiem, kas ir pilnībā skolotāja rīcībā. Skolām jāpiedāvā kvalitatīvi izstrādāti diagnosticējošo darbu paraugi noteiktu prasmju mērīšanai. Valsts līmenī diagnosticējot/monitorējot situāciju, jādomā par ticamu datu iegūšanu, veicot šos mērỉjumus korekti izvēelētās izlases kopās.

Daudz lielāka nozīme jāpiešķir aprobācijai un tajā iegūto datu analīzei, kas palīdzētu veidot kvalitatīvākus valsts mēroga pārbaudes darbus.

Skolēnu rezultāti uzrāda nepieciešamību pārskatīt, kā notiek prasmju mācīšana, vai tiek veidota stratēgija un ir strādāts, lai pārnestu no situācijas uz situāciju, no temata uz tematu, no priekšmeta uz priekšmetu, uz dzīvi. Jāpārskata, vai mācīšana nav pārprasti formalizējusies, jēgas izpratnes vietā veicot matemātiskus pārveidojumus, dažādos mācību priekšmetos katru faktu mācot nesaistīti ar kaut ko jaunu, nevis rādot, mācot saskatīt kopsakarības.

Skolēniem ir daudz labāki rezultāti uzdevumos, ar kuriem tiek pārbaudīta atsevišķa prasme, bet grūtības sagādā uzdevumi, kuros nepieciešams kombinēt vairākas prasmes. Mācību stundās būtisku prasmju vingrināšanai izmantojami dažādi konteksti. Jāpanāk lielāks kompleksu, kognitīvi dziḷu uzdevumu īpatsvars mācību procesā. Tas palīdzēs skolēniem veidot pārnesumu, dos pieredzi darboties jaunās situācijās.

Jāsekmē sadarbība starp matemātikas un dabaszinātṇu skolotājiem skolas un valsts līmenī. Nepaliekot tikai sarunu un plānošanas līmenī, bet skatoties stundās - kādas stratēǵijas katrs izmanto, kā māca tās atpazìt un pārnest. Tas sasaucas ar pašvadītas mācišanās prasmju nepieciešamu ienākšanu skolēna ikdienas pieredzē. Mācīt skolēnam veidot pārnesumu no zināmām uz svešām situācijām nav iespējams bez metakognitīvo stratēǵiju izmantošanas.

Skolēniem trīs gadu periodā ir nemainīgi pieticīgi rezultāti uzdevumos, kuros nepieciešamas prasmes darbā ar informāciju (tekstpratība). Skolotāju sadarbības loks vēl vairāk paplašināms, iesaistot savstarpējā pieredzes apmaiṇā un 
pilnveidē arī sākumskolas un citu mācību priekšmetu skolotājus, kas ir svarīgi, sekmējot skolēniem tik nepieciešamo lasišanas stratēǵiju, argumentēšanas un citu prasmju apguvi.

VISC jānodrošina skolas ar būtiskiem, mācišanas uzlabošanai izmantojamiem datiem par skolēnu rezultātiem valsts līmeṇa darbos.

\section{IZMANTOTĀ LITERATŪRA}

Biggs, J. B., \& Collis, K. F. (1982). Evaluating the Quality of Learning - the SOLO Taxonomy. New York: Academic Press.

Black, P. (1990). APU Science: The Past and the Future. School Science Review, 72(258), pp. 13-28.

Black, P., \& Wiliam, D. (2007). Large-scale assessment systems: Design principles drawn from international comparisons. Measurement: Interdisciplinary Research and Perspectives, 5(1), pp. 1-53. https://doi.org/10.1080/15366360701293386

Bond, T. G., \& Fox, C. M. (2007). Applying the Rasch model: Fundamental measurement in the human sciences ( $2^{\text {nd }}$ ed.). Mahwah, NJ: Lawrence Erlbaum.

Britton, E. D., \& Schneider, S. A. (2007). Large-scale assessments in science education. In Abell, S. K., \& Lederman, N. G. (eds.). Handbook of research on science education (pp. 1007-1040). Mahwah, NJ: Lawrence Erlbaum.

Darling-Hammond, L., \& Adamson, F. (2010). Beyond basic skills: The role of performance assessment in achieving $21^{\text {st }}$ century standards of learning. Stanford, CA: Stanford University, Stanford Center for Opportunity Policy in Education. Pieejams: https://scale. stanford.edu/system/files/beyond-basic-skills-role-performance-assessment-achieving21st-century-standards-learning.pdf (aplūkots 12.02.2018.).

France, I., Namsone, D., Čakāne, L., Dzērve, U., \& Vilciņš, J. (2016). Teaching to Use in Science and mathematics Previously Acquired Skills. SOCIETY. INTEGRATION. EDUCATION. Proceedings of the International Scientific Conference, 2016. Vol. II, (pp. 51-65). Rezekne: Rezeknes Academy of Technologies.

Kifer, E. (2000). Large-scale assessment: Dimensions, dilemmas, and policy. Thousand Oaks, CA: Corwin Press.

Liu, X. (2012). Developing Measurement Instruments for Science Education Research. No Fraser, B. J., Tobin, K., \& McRobbie, C. J. (red.). Second International Handbook of Science Education. Dordrecht: Springer Netherlands.

Millar, R. (2013). Improving svience education: Why assessment matters, Valuins assessment in science education. Pedagogy, curriculum, policy, Dordrexht Springer pp. 55-68.

Namsone, D., \& Cakane, L. (2015). How the absence of higher PISA scores is connected with Science Classroom? Paper presenter at the $5^{\text {th }}$ World Conference on Educational Technology Researsh, North Cyprus.

Namsone, D., Cakane, L., \& Cirulis, A. (2017). How does cognitive demand in observed lessons and national diagnostic testing compare to PISA science results in Latvia? $12^{\text {th }}$ Conference of the European Science Education Research Association (ESERA), 21-25.2017. Dublin, Ireland. 
Panizzon, D., Pegg, J. (2003). Using a cognitive structural model to provide new insights into students' understandings of diffusion. International Journal of Science Education, 25(12), pp. 1427-1450.

Stiggins, R. J., Arter, J. A., Chappuis, J., \& Chappius, S. (2004). Classroom assessment for student learning: Doing it right - using it well. Portland, Oregon: Assessment Training Institute.

Volkinsteine, J., Namsone, \& D., Cakane, L. (2015). What lesson observation data reveal about the changes in teaching science: Case study from Latvia, International Baltic Symposium on Science and Technology Education, BalticSTE 2015 (15.-18.06.2015., Šaul̦i, Lietuva).

Wilson, M. (2005). Constructing measures: an item response modeling approach. Mahwah, N. J: Lawrence Erlbaum Associates.

Wylie, E. C., \& Wiliam, D. (2006). Diagnostic questions: is there value in just one? Paper presented at the Annual Meeting of the National Council on Measurement in Education held at San Francisco, CA.

Wu, M., Tam, H. P., \& Jen, T. H. (2016). Educational Measurement for Applied Researchers. Springer, Singapore. 